\title{
Minireviews
}

\section{Genetic and Molecular Regulation of Extrasynaptic GABA-A Receptors in the Brain: Therapeutic Insights for Epilepsy}

\author{
Shu-Hui Chuang and Doodipala Samba Reddy \\ Department of Neuroscience and Experimental Therapeutics, College of Medicine, Texas A\&M University Health Science Center, \\ Bryan, Texas
}

Received August 17, 2017; accepted November 13, 2017

\begin{abstract}
GABA-A receptors play a pivotal role in many brain diseases. Epilepsy is caused by acquired conditions and genetic defects in GABA receptor channels regulating neuronal excitability in the brain. The latter is referred to as GABA channelopathies. In the last two decades, major advances have been made in the genetics of epilepsy. The presence of specific GABAergic genetic abnormalities leading to some of the classic epileptic syndromes has been identified. Advances in molecular cloning and recombinant systems have helped characterize mutations in GABA-A receptor subunit genes in clinical neurology. GABA-A receptors are the prime targets for neurosteroids (NSs). However, GABA-A receptors are not static but undergo rapid changes in their number or composition in response to the neuroendocrine milieu. This
\end{abstract}

review describes the recent advances in the genetic and neuroendocrine control of extrasynaptic and synaptic GABA-A receptors in epilepsy and its impact on neurologic conditions. It highlights the current knowledge of GABA genetics in epilepsy, with an emphasis on the neuroendocrine regulation of extrasynaptic GABA-A receptors in network excitability and seizure susceptibility. Recent advances in molecular regulation of extrasynaptic GABA-A receptor-mediated tonic inhibition are providing unique new therapeutic approaches for epilepsy, status epilepticus, and certain brain disorders. The discovery of an extrasynaptic molecular mechanism represents a milestone for developing novel therapies such as NS replacement therapy for catamenial epilepsy.

\section{Introduction}

Alterations in the structure and function of neurotransmitter receptors play critical roles in the pathophysiology of many brain diseases. Epilepsy is one of the most widespread and debilitating neurologic disorders, affecting approximately 3.4 million people in the United States and 65 million people worldwide. This disorder is a chronic condition characterized by two or more unpredicted and unprovoked seizures occurring due to excessive or hypersynchronous electrical

This work was supported by the CounterACT Program, National Institutes of Health, Office of the Director and the National Institute of Neurologic Disorders and Stroke [Grant U01 NS083460]. No potential conflicts of interest relevant to this article were reported.

https://doi.org/10.1124/jpet.117.244673. discharge of neurons in the brain (Hauser 1994; Thurman et al., 2011; Hesdorffer et al., 2013). Many subregions and a wide variety of neurotransmitters are involved in the pathology of epileptic seizures. The GABA-A receptor, a subtype of receptor activated by the inhibitory neurotransmitter GABA, is a prime target for many seizure medications. Although antiepileptic drugs allow for symptomatic control of seizures, epilepsy remains incurable, partially due to our poor understanding of the molecular and electrophysiological basis of epilepsy development. Advances in our understanding of the pathology of epilepsy are crucial for discovering effective treatments for epilepsy and related brain disorders.

Current knowledge indicates that approximately $60 \%$ of epilepsy is idiopathic and $40 \%$ stems from developmental or

\footnotetext{
ABBREVIATIONS: AP, allopregnanolone (3 $\alpha$-hydroxy-5 $\alpha$-pregnan-20-one); BLA, basolateral amygdala; bp, base pair; CAE, childhood absence epilepsy; CaMKII, Ca2+/calmodulin-dependent protein kinase II; CNS, central nervous system; DGGC, dentate gyrus granule cell; DHEAS, dehydroepiandrosterone sulfate; DKO, GABA-A receptor $\delta$ subunit knockout; DS, Dravet syndrome; ER, endoplasmic reticulum; FS, febrile seizure; GABRA, gene encoding the GABA-A receptor $\alpha$ subunit; GABRB, gene encoding the GABA-A receptor $\beta$ subunit; GABRD, gene encoding the GABA-A receptor $\delta$ subunit; GABRG, gene encoding the GABA type A receptor $\gamma$ subunit; GEFS + , generalized epilepsy with febrile seizures plus; GX, ganaxolone ( $3 \alpha$-hydroxy-3 $\beta$-methyl- $5 \alpha$-pregnan-20-one); HEK, human embryonic kidney; JME, juvenile myoclonic epilepsy; mIPSC, miniature inhibitory postsynaptic current; NS, neurosteroid; OP, organophosphate; PKA, protein kinase A; PKC, protein kinase C; SE, status epilepticus; THDOC, allotetrahydrodeoxycorticosterone ( $3 \alpha, 21$-dihydroxy- $5 \alpha$-pregnan-20-one); THIP, gaboxadol (4,5,6,7-tetrahydroisoxazolo-[5,4-c]pyridin-3ol); TM, transmembrane domain; WT, wild-type.
} 
acquired conditions such as a stroke, traumatic brain injury, infections, tumor, drug withdrawal, neurotoxicity, or prolonged seizures and genetic defects (Eslami et al., 2016; Pitkänen et al., 2016; Vezzani et al., 2016). The underlying mechanisms that render a normal brain to progressively develop into a brain with recurring seizures are still elusive. Along with age- and sex-related factors, other physiologic abnormalities in neurotransmitter release, functions of ion channels, synaptic connectivity, neural circuitries, or the interaction of these factors facilitate seizure development. The term "epileptogenesis" is used to describe the complicated process of the development of acquired epilepsy. Epileptogenesis denotes a plastic progression in which the balance of neuronal excitation/inhibition, neuronal interconnections, and neuronal circuits undergo gradual changes during or after a series of insults and, consequently, transform a normal brain into one that is hyperexcitable, suffers neuronal loss and damage, and, as a result, has recurrent spontaneous seizures.

In this article, we describe briefly the emerging concepts on GABA genetics in epilepsy, with a special emphasis on the functional role of extrasynaptic GABA-A receptors in the regulation of network excitability and susceptibility to brain disorders. We also highlight the potential therapeutic implications of modulating extrasynaptic GABA-A receptor-mediated tonic inhibition in pharmacotherapy of epilepsy, status epilepticus (SE), and other brain disorders.

\section{Molecular Pharmacology of Neuronal GABA-A Receptors}

GABA-A Receptor Subtypes. GABA is the most abundant inhibitory neurotransmitter in the brain. It is a highly hydrophilic molecule and hence cannot cross the blood-brain barrier. GABA is synthesized in neurons and stored in synaptic vesicles. Upon neuronal activation, GABA is released from the vesicles into the synapse, where it can act on postsynaptic receptors, or diffuse into the extracellular space. GABA binds with three receptors: GABA-A, GABA-B, and GABA-C. GABA-A receptor plays a pivotal role in regulating neuronal excitability and in the pathology of epilepsy (Baulac et al., 2001). GABA exerts fast inhibitory actions by activating postsynaptic GABA-A receptors in the brain, causing the influx of negatively charged chloride ions and hyperpolarization of neurons which serve to reduce neuronal excitability and firing. GABA-A receptors are pentamers consisting of five subunits. Each subunit has one long extracellular $\mathrm{N}$ terminus that interacts with a variety of drugs, including benzodiazepines, barbiturates, and neurosteroids (NSs); four transmembrane domains (TMs) (TM1-TM4); and one short intracellular loop that links TM1 and TM2, one short extracellular loop that links TM2 and TM3, one long intracellular loop that links TM3 and TM4 and can be modulated by phosphorylation, and one small extracellular C terminus. The TM2 of each subunit forms a selective channel pore that is permeable for the chloride ion passage (Fig. 1). GABA-A receptor isoform distribution plays key roles in regulation of sedation, hypnosis, anxiolysis, anesthesia, and seizure protection (Table 1).

GABA-A receptors are made from a repertoire of 19 known subunits, as follows: $\alpha 1-6, \beta 1-3, \gamma 1-3, \delta, \varepsilon, \theta, \pi$, and $\rho 1-3$. The most general stoichiometry of GABA-A receptors contains two $\alpha$ subunits, two $\beta$ subunits, and one $\gamma$ subunit, or one $\delta$ subunit. GABA-A receptor subunits have discrete distributions among different brain regions. Approximately $90 \%$ of GABA-A receptors are $\gamma$-containing, but the $\delta$ subunit can substitute for $\gamma$. The $\delta$ subunit has more confined expression in parts of the brain such as the hippocampus, cerebellum, and thalamus. GABA binding sites are located at the junction between subunits $\alpha$ and $\beta$, and benzodiazepines bind at the interface between subunits $\alpha$ and $\gamma$. The genomic location of 19 GABA-A receptor subunits has been identified (Russek, 1999). The genes encoding subunits $\alpha 2, \alpha 4, \beta 1$, and $\gamma 1$ cluster on chromosome $4 \mathrm{p} 12$; subunit $\alpha 1, \alpha 6, \beta 2, \gamma 2$, and $\pi$ genes are mapped on chromosome 5q; subunit $\alpha 5, \beta 3$, and $\gamma 3$ genes cluster on chromosome $15 q 12$; subunit $\alpha 3, \theta$, and $\varepsilon$ are located on chromosome Xq28; $\rho 1$ and $\rho 2$ cluster on chromosome $6 q 15$; and the $\rho 3$ and $\delta$ subunits are found on chromosome $3 q 11.2$ and chromosome 1p36.3, respectively (Fig. 2).

Synaptic Versus Extrasynaptic GABA-A Receptors. GABA-A receptors are divided into two categories according to their localization: synaptic and extrasynaptic receptors. Each type of receptor possesses distinct characteristics in its affinity and efficacy to GABA, desensitization rate, and response to benzodiazepines and NSs (Bianchi and Macdonald, 2002, 2003; Brown et al., 2002; Wohlfarth et al., 2002; Mortensen et al., 2012). Extrasynaptic GABA-A receptors are composed of mainly $\delta$-containing receptors, which have high GABA affinity but low efficacy, low desensitization rate, and low sensitivity to benzodiazepines, and are highly potentiated by NSs compared with synaptic GABA-A receptors (Table 2). Activation of synaptic $\gamma$-containing GABA-A receptors and extrasynaptic $\delta$-containing GABA-A receptors produce phasic and tonic current inhibition, respectively. Rapid and transient phasic current inhibition is generated by presynaptic GABA release and the binding of synaptic $\gamma$-containing GABA-A receptors, whereas tonic current inhibition is produced by persistent activation of perisynaptic or extrasynaptic $\delta$-containing GABA-A receptors by ambient GABA. Extrasynaptic receptors are only found in specific brain areas such as the hippocampus, amygdala, neocortex, thalamus, hypothalamus, and cerebellum (Stell et al., 2003; Jia et al., 2005; Drasbek and Jensen, 2006; Olmos-Serrano et al., 2010; Mortensen et al., 2012; Carver et al., 2014). Extrasynaptic $\delta$-containing GABA-A receptors are tailored to regulate neuronal excitability by controlling the basal tone through shunting and tonic inhibition in neurons (Coulter and Carlson, 2007; Carver and Reddy 2013). They are mostly insensitive to allosteric modulation by benzodiazepines such as midazolam (Reddy et al., 2015; Carver and Reddy, 2016).

NSs are powerful modulators of GABA-A receptors and can rapidly alter neuronal excitability (Reddy and Estes, 2016). NSs act at both synaptic and extrasynaptic GABA-A receptors, but they are more efficacious on extrasynaptic $\delta$ GABA-A receptors that mediate tonic inhibition. At low concentrations (submicromolar level), NSs allosterically potentiate GABA-A receptor currents, whereas at high concentrations (micromolar level), NSs can directly activate GABA-A receptors by binding directly at the orthosteric site (Reddy and Rogawski, 2002; Hosie et al., 2007; Reddy and Jian, 2010; Carver and Reddy, 2016). One recent study (Joshi et al., 2017) demonstrated a downregulation of the $\delta$-containing GABA-A receptors prior to the onset of epilepsy, and a reduction in NS-induced modulation of tonic inhibition in the SE model of epilepsy, highlighting the role of $\delta \mathrm{GABA}-\mathrm{A}$ receptors in this disease. 


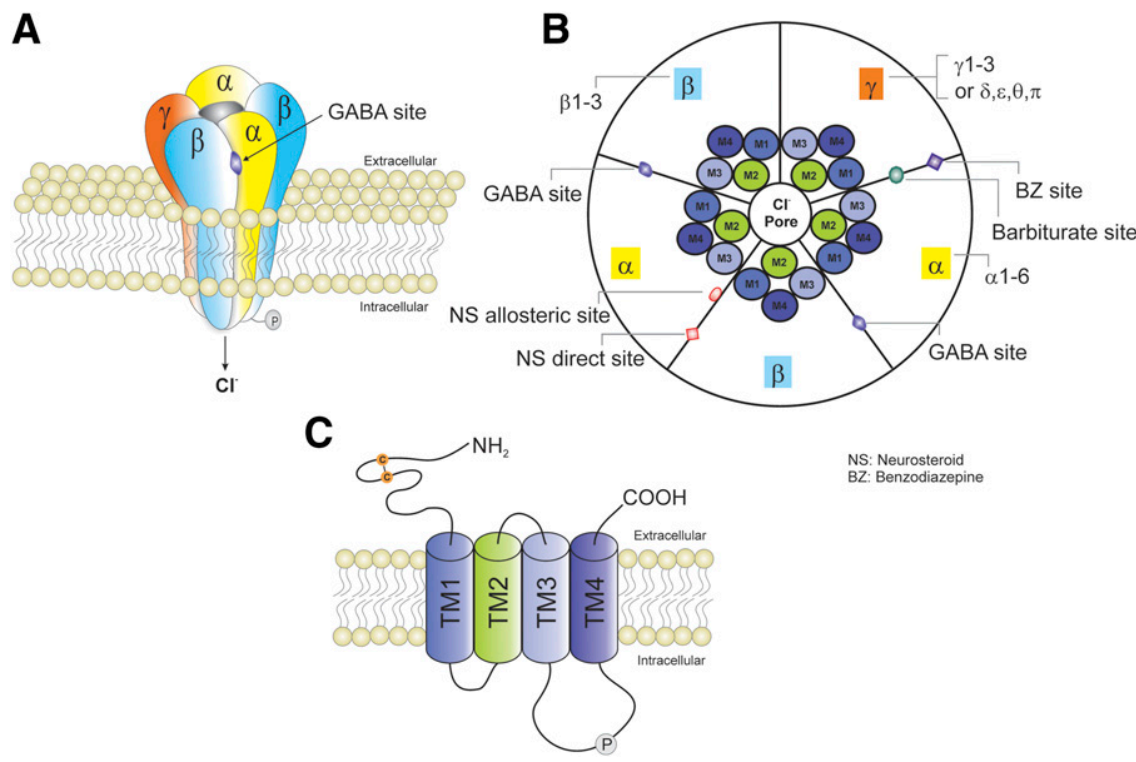

Fig. 1. Schematic representation of typical GABA-A receptor (GABA-AR) structure and subunit composition. (A) GABA-ARs are heteropentamers forming a channel that is permeable to chloride ion passage. (B) A top view of the pentamer. GABA-ARs are made from a repertoire of $19 \mathrm{known}$ subunits: $\alpha 1-6, \beta 1-3, \gamma 1-3, \delta, \varepsilon, \theta, \pi$, and $\rho 1-3$. The most general stoichiometry of GABA-ARs contains two $\alpha \mathrm{s}$, two $\beta \mathrm{s}$, and one $\gamma$; and the $\gamma$ subunit can be substituted by $\delta, \varepsilon, \theta$, or $\pi$. Each subunit has four TMs (TM1-TM4). TM2s form a selective channel pore. GABA exerts fast inhibitory actions by activating postsynaptic GABA-ARs in the brain, causing the influx of negatively charged chloride ions and hyperpolarization of neurons, which serve to reduce neuronal excitability and firing. The GABA binding sites are located at the junction between subunit $\alpha$ and $\beta$, whereas benzodiazepines (BZs) bind at the interface between subunits $\alpha$ and $\gamma$. Barbiturates binding sites are distinct from the BZ binding site. The NSs have two putative binding sites including allosteric and direct binding sites. The allosteric binding site is located at the $\alpha$ subunit TMs, whereas the direct binding site is within the TMs of the $\alpha$ and $\beta$ subunits. (C) GABA-ARs belong to the Cys-loop family of ligand-gated ion channels, which also contains nicotinic acetylcholine, glycine, and serotonin 5-HT3 receptors. Each subunit has one long extracellular N terminus that interacts with a variety of drugs including BZs, barbiturates, and NSs; four TMs (TM1-TM4); and one short intracellular loop that links TM1 and TM2, one short extracellular loop that links TM2 and TM3, one long intracellular loop that links TM3 and TM4 and can be modulated by phosphorylation, and one small extracellular C terminus.

Distribution of GABA-A Receptor Subtypes. Different subtype combinations respond differently to receptor modulators and contribute distinct functions in each brain area. GABA-A receptors have a high molecular heterogeneity because of the abundance of available subunits and the ways in which those subunits can be assembled to form the heteropentameric receptors. The composition and distribution of the GABA-A receptor isoforms are listed in Table 3. Receptors located in the synaptic sites are primarily made of $\alpha, \beta$, and $\gamma 2$ subunits. $\alpha 1, \alpha 2, \alpha 3$, and $\alpha 5$-containing receptors are generally sensitive to benzodiazepines. $\gamma$ Subunit-containing receptors constitute the majority of GABA-A receptors. Immunohistochemistry and in situ hybridization data showed that $\alpha 1 \beta 2 \gamma 2$ is the most abundant and widespread subtype, accounting for $\sim 43 \%-60 \%$ of all GABA-A receptors in the adult brain (McKernan and Whiting, 1996; Loup et al., 2000; Möhler et al., 2002). It mostly appears in the synaptic sites. $\alpha 2 \beta 3 \gamma 2$ and $\alpha 3 \beta 3 \gamma 2$ receptors, located mostly in the synaptic sites, are also highly prevalent. They represent $\sim 15 \%-20 \%$ and $\sim 10 \%-15 \%$ of all GABA-A receptors, respectively. $\alpha 4 \beta \gamma$ and $\alpha 4 \beta \delta$, located in the synaptic and extrasynaptic locations, respectively, represent approximately 5\%, whereas synaptic $\alpha 5 \beta 1 / 3 \gamma 2$ and $\alpha 6 \beta 2 / 3 \gamma 2$ account for less than 5\% (McKernan and Whiting, 1996; Pirker et al., 2000; Möhler et al., 2002). Other subtypes have more specific and confined distribution patterns (Fig. 3).

Receptors located in the extrasynaptic locations usually contain the $\delta$ subunit rather than the $\gamma$ subunit in association with $\beta 2$ or $\beta 3$ and a certain isoform of the $\alpha$ subunit. The $\delta$ subunit with its highly specific regional and subcellular distribution is tailored to generate tonic inhibition. It is abundant in cerebellar and dentate gyrus granule cells (DGGCs), some cortical neurons, and thalamic relay cells
(Wisden et al., 1992; Fritschy and Mohler, 1995; Sperk et al., 1997; Pirker et al., 2000; Peng et al., 2002).

In the hippocampus, several isoforms are expressed in distinct regions and cell types. CA1 pyramidal neurons mainly contain $\alpha 5 \beta 3 \gamma 2 \mathrm{~S}$ receptors, which are located at both synaptic and extrasynaptic sites. However, DGGCs, which have the second highest density of $\delta$ subunits, express $\alpha 3 \beta 3 \gamma 2 \mathrm{~S}$ and $\alpha 4 \beta 2 / 3 \delta$ receptors in the synaptic and extrasynaptic site,

\section{TABLE 1}

The pharmacological roles of select GABA-A receptor subunits + , related; -, not related.

The data are obtained from the references listed below. (Homanics et al., 1997 Mihalek et al., 1999; Rudolph et al. 1999; Löw et al, 2000; McKernan et al., 2000; Collinson et al., 2002; Crestani et al., 2002; Blednov et al., 2003; Jurd et al., 2003; Kralic et al., 2003; Chandra et al., 2005; Wiltgen et al., 2005; Nutt 2006; Jia et al., 2007; Carver et al., 2014).

\begin{tabular}{|c|c|c|c|c|c|c|c|c|c|}
\hline & $\alpha 1$ & $\alpha 2$ & $\alpha 3$ & $\alpha 4$ & $\alpha 5$ & $\beta 2$ & $\beta 3$ & $\gamma 2$ & $\delta$ \\
\hline Anxiety & & & & & & & & + & - \\
\hline Learning memory & & & & & + & & & & $-/+$ \\
\hline Seizure/epilepsy & + & - & - & & - & & + & & \\
\hline Effects of benzodiazepines & & & & & & & & & \\
\hline Motor impairment & - & - & - & & - & & & & \\
\hline Sedation & + & - & - & & - & + & & & \\
\hline Anxiolysis & - & + & + & & - & & & & \\
\hline Myorelaxation & - & & + & & & & & & \\
\hline Anticonvulsant & + & - & - & & - & & & & \\
\hline Effects of neurosteroids & & & & & & & & & \\
\hline Motor impairment & - & & & & & & & & \\
\hline Hypnosis & - & & & & & & & & + \\
\hline Anxiolysis & & & & & & & & & + \\
\hline Anticonvulsant & & & & & & & & & + \\
\hline Effects of other drugs & & & & & & & & & \\
\hline Sedation & & & & + & & & & & \\
\hline Anesthesia & & & & + & & & + & & - \\
\hline
\end{tabular}


A

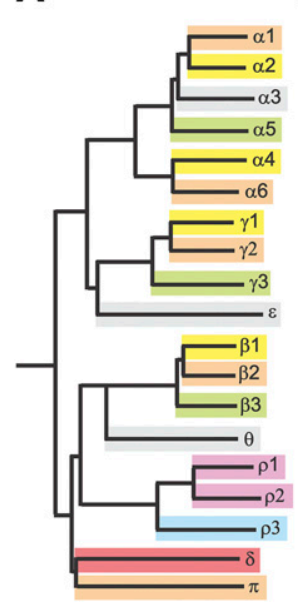

B

\begin{tabular}{ccccc}
\hline Chromoso & Location & Subunit & Gene & Gene ID \\
\hline $\mathbf{1}$ & $1 \mathrm{p} 36.3$ & $\delta$ & GRBRD & 2563 \\
$\mathbf{3}$ & $3 \mathrm{q} 11.2$ & $\rho 3$ & GRBRR3 & 200959 \\
$\mathbf{4}$ & $4 \mathrm{p} 12$ & $\alpha 2$ & GRBRA2 & 2555 \\
& & $\alpha 4$ & GRBRA4 & 2557 \\
& & $\beta 1$ & GRBRB1 & 2560 \\
$\mathbf{5}$ & $5 \mathrm{q} 34$ & $\alpha 1$ & GRBRA1 & 2554 \\
& $5 \mathrm{q} 34$ & $\alpha 6$ & GRBRA6 & 2559 \\
& $5 \mathrm{q} 34$ & $\beta 2$ & GRBRB2 & 2561 \\
& $5 \mathrm{q} 34$ & $\gamma 2$ & GRBRG2 & 2566 \\
$\mathbf{6}$ & $6 \mathrm{q} 15$ & $\rho 1$ & GRBRR1 & 2569 \\
& & & GRBRR2 & 2570 \\
$\mathbf{1 5}$ & $15 \mathrm{q} 12$ & $\alpha 5$ & GRBRA5 & 2558 \\
& & $\beta 3$ & GRBRB3 & 2562 \\
$\mathbf{X}$ & Xq28 & $\alpha 3$ & GRBRA3 & 2556 \\
& & $\theta$ & GRBRQ & 55879 \\
\hline
\end{tabular}

TABLE 2

Characterization of synaptic ( $\alpha \beta \gamma 2$-containing) and extrasynaptic ( $\alpha \beta \delta$-containing) GABA-A receptors in the brain

\begin{tabular}{|c|c|c|}
\hline & $\begin{array}{c}\text { Synaptic } \\
\text { GABA-A Receptors }\end{array}$ & $\begin{array}{c}\text { Extrasynaptic } \\
\text { GABA-A Receptors }\end{array}$ \\
\hline Subunits & $\begin{array}{l}\text { Pentamer } \\
\quad(\gamma 2 \text {-containing })\end{array}$ & $\begin{array}{l}\text { Pentamer } \\
\quad(\delta \text {-containing })\end{array}$ \\
\hline Inhibition & Phasic & Tonic \\
\hline GABA affinity & Low & High \\
\hline GABA efficacy & High & Low \\
\hline Desensitization & Pronounced & Moderate/low \\
\hline Benzodiazepines & Sensitive & Insensitive \\
\hline NSs & Potentiated & Highly potentiated \\
\hline $\begin{array}{l}\text { Low }\left[\mathrm{Zn}^{2+}\right] \\
\text { blockade }\end{array}$ & $\mathrm{N}$ & $\mathrm{Y}$ \\
\hline Distribution & Highly prevalent & $\begin{array}{l}\text { Highly specific regional } \\
\text { (e.g., hippocampus, } \\
\text { neocortex, thalamus, } \\
\text { hypothalamus, cerebellum) }\end{array}$ \\
\hline
\end{tabular}

$\alpha 3 \beta 2 / 3 \gamma 2$ ) are the predominant synaptic receptor subtypes that produce phasic inhibition, whereas receptors containing $\alpha 4, \alpha 5, \alpha 6$, or $\delta$ subunits $(\alpha 4 \beta \delta, \alpha 6 \beta \delta$, and $\alpha 5 \beta \gamma 2)$ are the primary extrasynaptic receptor subtypes that generate tonic inhibition.

\section{Genetic Regulation of GABA-A Receptors}

the $\alpha 4$ and/or $\alpha 6$ subunit. $\alpha 4 \beta 2 / 3 \delta$ or $\alpha 6 \beta 2 / 3 \delta$ combination exhibit the highest GABA affinity with a GABA $\mathrm{EC}_{50}$ in the nanomolar range. $\alpha 1 \beta 2 \delta$ receptors are primarily present in hippocampal interneurons and show lower GABA potency compared with the $\alpha 4 \beta 2 / 3 \delta$ combination. Overall, $\alpha 1, \alpha 4, \gamma 2$, and $\delta$ subunits are found to be expressed in the extrasynaptic sites of hippocampus (Sun et al., 2004; Glykys and Mody, 2007; Mortensen et al., 2012).

In the cerebellum, cerebellar granule cells, which contain the highest density of $\delta$ subunits in the central nervous system (CNS), express $\alpha 6 \beta 2 / 3 \delta$ predominantly at extrasynaptic sites. $\alpha 6 \beta 3$ and $\alpha 6 \beta 3 \gamma 2 \mathrm{~S}$ combinations are also found in cerebellar granule cells (Nusser et al., 1998; Farrant and Nusser, 2005; Zheleznova et al., 2009). Notably, $\alpha 6$-containing receptors are almost exclusively expressed in the cerebellar granule cells and, in combination with the $\delta$ subunit, exhibit the highest GABA potency. In the thalamus, $\alpha 4 \beta 3 \gamma 2 \mathrm{~S}$ receptors are expressed at synaptic sites in the thalamic relay cells, whereas, $\alpha 4 \beta 3$ and $\alpha 4 \beta 3 \delta$ receptors are expressed at extrasynaptic sites. In addition, $\alpha 3 \beta 3$ receptors are also found in the thalamus.

In the amygdala, the $\alpha 2$ subunit, primarily found in principal neurons, is responsible for the allosteric action of the benzodiazepines (Marowsky et al., 2004). The principal neurons in the basolateral amygdala (BLA) also contain $\gamma 2$ subunits, which contribute to the fast synaptic inhibition (Esmaeili et al., 2009). The benzodiazepine-sensitive $\alpha 2 \beta \gamma 2$ subtypes are thought to be assembled in the principal neurons of the BLA in the synaptic site and generate phasic inhibition. Extrasynaptic GABA-A receptors in the BLA are made up mainly of the $\alpha 3, \alpha 5$, and the $\delta$ subunits, which contribute to nondesensitizing tonic current inhibition. In particular, $\alpha 3$ subunit is strongly expressed throughout the BLA nucleus and is responsible for the majority of tonic inhibition since significant reduction of tonic currents was observed in the BLA neurons from $\alpha 3$ subunit knockout mice (Farrant and Nusser, 2005; Marowsky et al., 2012).

In general, receptors containing a $\gamma 2$ subunit in combination with $\alpha 1, \alpha 2$, or $\alpha 3$ subunits $(\alpha 1 \beta 2 / 3 \gamma 2, \alpha 2 \beta 2 / 3 \gamma 2$, and

GABA Epilepsy Genetics. GABA-A receptors play a pivotal role in regulating neuronal inhibition in the CNS. Dysregulation of neuronal activity and changes in the composition and function of GABA-A receptors contribute to the development of epilepsy. Genetic epilepsies are genetically driven recurrent seizures caused by mutations in genes governing excitation and inhibition. Mutations in GABA-A receptor subunit genes have been involved in the pathophysiology of several idiopathic generalized epilepsies. Specifically, mutations in the gene encoding the GABA-A receptor $\alpha 1$ subunit (GABRA1) and the gene encoding the GABA-A receptor $\beta 3$ subunit (GABRB3) are mainly associated with childhood absence epilepsy (CAE) and juvenile myoclonic epilepsy (JME), whereas mutations in the gene encoding the GABA-A receptor $\gamma 2$ subunit (GABRG2) and the gene encoding the GABA-A receptor $\delta$ subunit (GABRD) are associated with febrile seizures (FSs), generalized epilepsy with FS plus (GEFS+), and Dravet syndrome (DS) (Fig. 4; Table 4).

Mutations of $\alpha \mathbf{1}$ Subunit. A heterozygous missense mutation (A322D) in the TM3 of GABRA1 was identified in an autosomal dominant form of JME in a French Canadian family. This mutation arises by the replacement of the alanine amino acid residue by a larger negatively charged aspartate in the helix of TM3 of the $\alpha 1$ subunit. In in vitro studies, HEK293 cells expressing this mutant GABA-A receptor $\left(\alpha 1_{\mathrm{A} 322 \mathrm{D}} \beta 2 \gamma 2\right)$ exhibited reduced GABA-evoked currents, GABA sensitivity, and $\alpha 1$ subunit protein expression, along with altered current kinetics and accelerated receptor endocytosis and endoplasmic reticulum (ER)-associated degradation via the ubiquitinproteasome system (Cossette et al., 2002; Gallagher et al., 2004, 2007; Krampfl et al., 2005; Bradley et al., 2008; Ding et al., 2010). One study (Ding et al., 2010) indicated that this mutant GABA-A receptor $\left(\alpha 1_{\mathrm{A} 322 \mathrm{D}} \beta 2 \gamma 2\right)$ causes a dominant negative effect on the composition and surface expression of wild-type (WT) GABA-A receptors. Therefore, the A322D mutation in human GABRA1 results in a loss of function of 


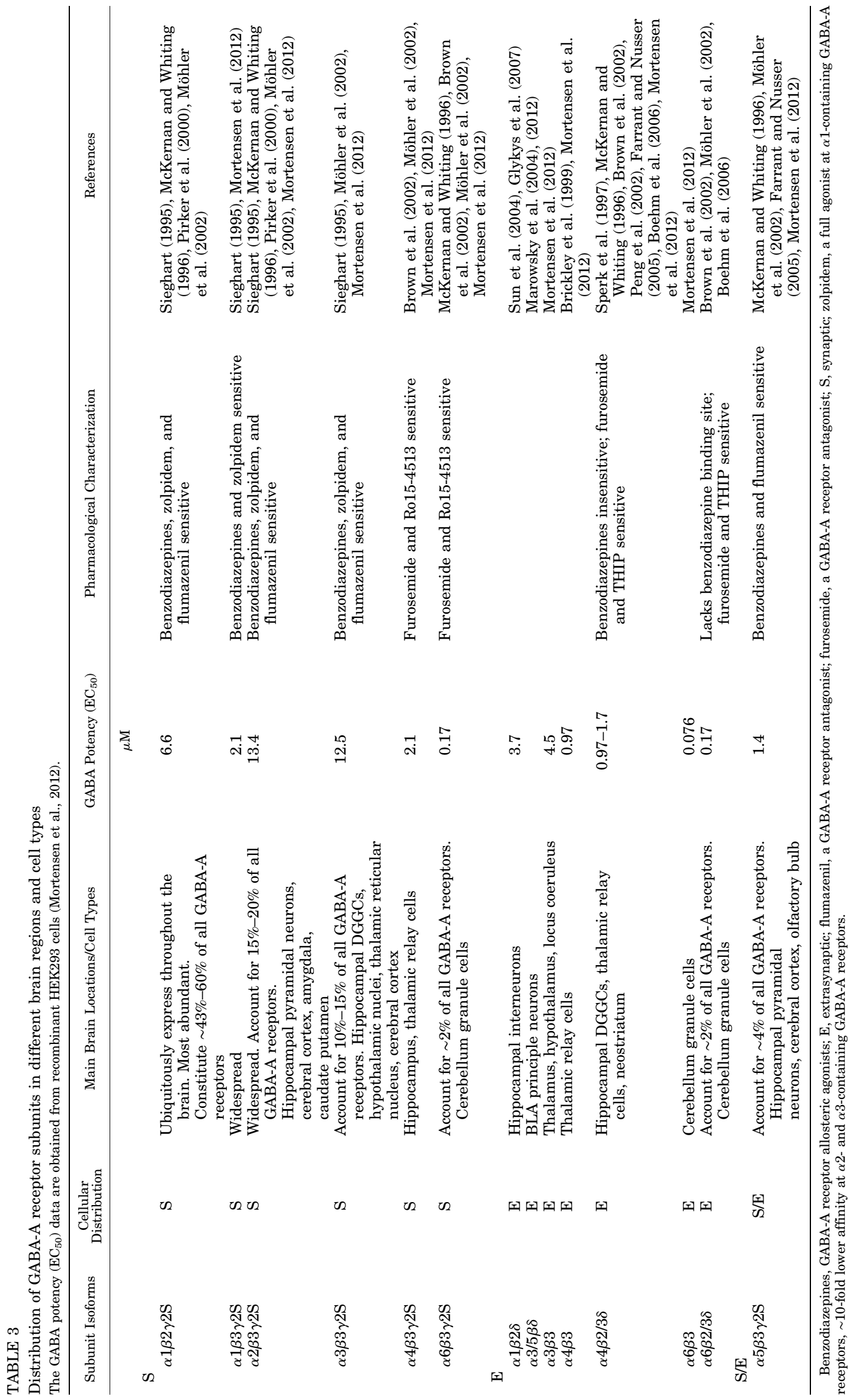


A

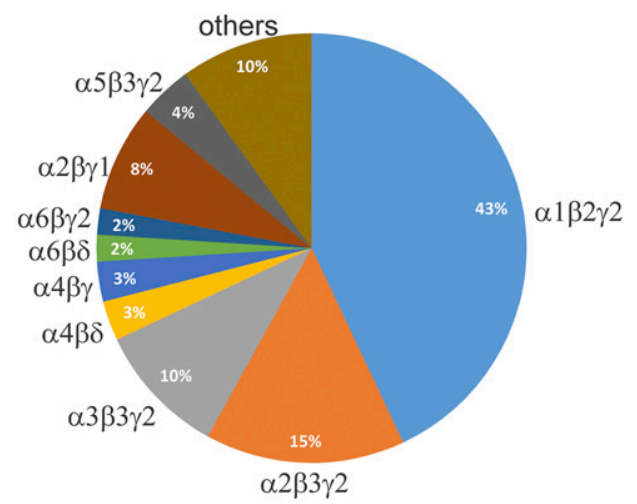

B

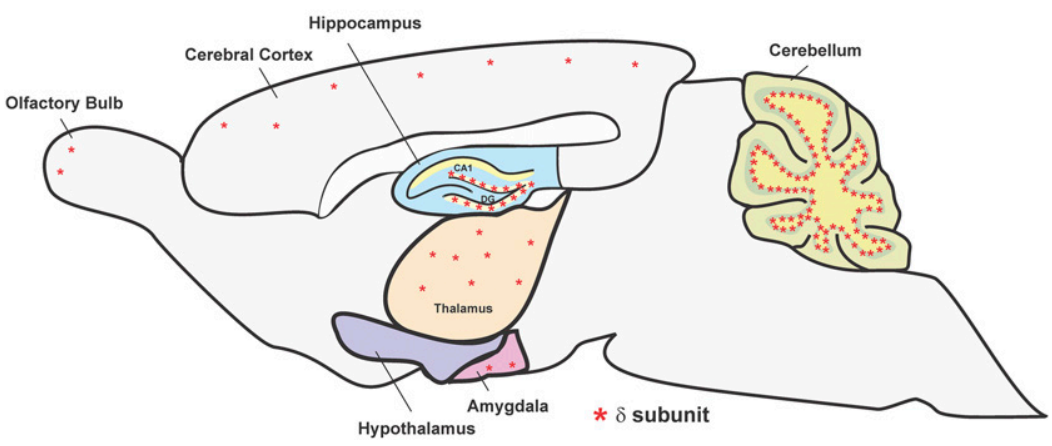

Fig. 3. Extrasynaptic GABA-A receptor $\delta$ subunit distribution. (A) The estimated abundance of GABA-A receptor subtypes in the rodent brain. (B) GABA-A receptor $\delta$ subunit distribution. *denotes $\delta$ subunit. the receptor via several mechanisms, including the alteration of receptor functions, a reduction in receptor surface expression, and decreased receptor lifetime on the cell membrane.

A single base pair (bp) deletion (975delC) in GABRA1 was found in a patient with sporadic CAE among 98 unrelated patients with idiopathic generalized epilepsy (IGE), a generalized epilepsy with a strong underlying genetic basis. This de novo mutation causes a frameshift and a premature stop codon (S326fs328X), leading to a truncation in the TM3- and ER-associated degradation. In addition, GABA-evoked currents were not detected in the HEK293 cells with mutant $\alpha 1$-containing GABA-A receptors. These mutant receptors were not able to be incorporated into the membrane surface, highlighting the involvement of the $\alpha 1$ subunit in inserting the receptors into the cell membrane and the overall functional integrity of the GABA-A receptor (Maljevic et al., 2006). However, no dominant negative effects on the WT receptors were observed in these mutant receptors. These findings reveal that a single bp deletion in GABRA1 causes a loss of function and haploinsufficiency of the GABA-A receptors.

Two other mutations in GABRA1 associated with impaired membrane delivery of the mature GABA-A receptor were also identified in a cohort of French Canadian families with IGE. A 25-bp insertion associated with intron results in the deletion of the TM4 and a premature stop codon (K353delins18X), and a missense mutation that replaces the aspartate 219 residue with an asparagine (D219N). The family with K353delins18X mutation displays afebrile, generalized tonic-clonic seizures, whereas the family with the D219N mutation in GABRA1 shows mainly FSs and absence seizures (Lachance-Touchette et al., 2011). In addition, four novel de novo mutations in GABRA1 were also found in SCN1A-negative patients with DS, providing insight into more genetic causes for this syndrome (Carvill et al., 2014). Recently, several novel mutations in the extracellular $\mathrm{N}$ terminus of TM1 or TM2 of GABRA1 have been implicated in several epileptic diseases including infantile epilepsy, West syndrome, Ohtahara syndrome, and early onset epileptic encephalopathy (Johannesen et al., 2016; Kodera et al., 2016). Mutations in GABRA1 of GABA-A receptors contribute to the genetic etiology of both mild generalized epilepsies and severe epilepsy syndromes.

Mutations of $\boldsymbol{\beta 3}$ Subunit. The association of GABRB3 with idiopathic generalized epilepsies was first reported in

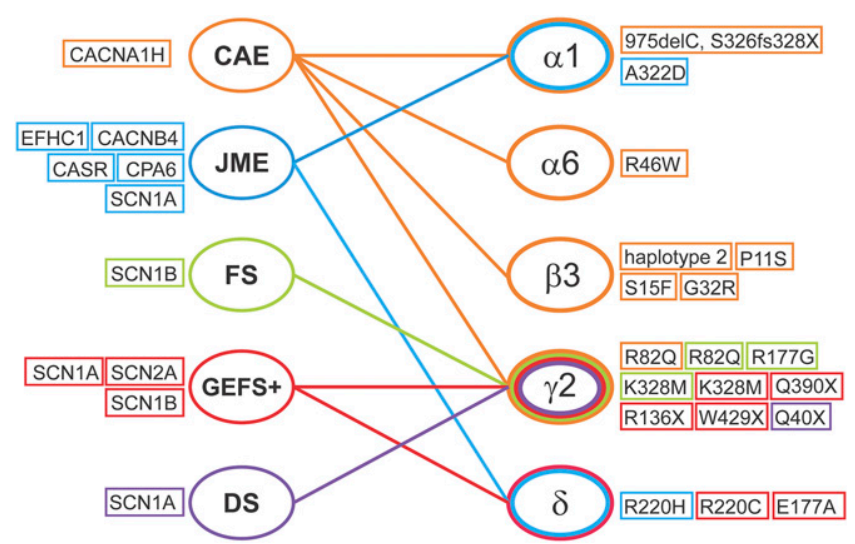

Fig. 4. Summary outline of the association of genetic epilepsies with GABA-A receptor subunits and other genetic factors. (Right) GABA-A receptor subunits that are involved in genetic epilepsies. Mutations in each subunit are listed. (Left) Other genetic factors that are associated with genetic epilepsies. CACNA1H ( $\left.\mathrm{Ca}_{\mathrm{v}} 3.2\right)$, a voltage-dependent T-type calcium channel $\alpha 1 \mathrm{H}$ subunit gene; CACNB4, a voltage-dependent L-type calcium channel $\beta$ subunit gene; CPA6, a gene that encodes carboxypeptidase A6; CASR, a gene that encodes calcium sensor receptor; EFHC1, a gene that encodes a protein with an EF-hand domains; SCN1A, a sodium voltage-gated channel $\alpha 1 \mathrm{~A}$ subunit gene; SCN1B, a sodium voltage-gated channel $\alpha 1 \mathrm{~B}$ subunit gene; SCN2A, a sodium voltage-gated channel $\alpha 2 \mathrm{~A}$ subunit gene; SCN2B, a sodium voltage-gated channel $\alpha 2 \mathrm{~B}$ subunit gene. 


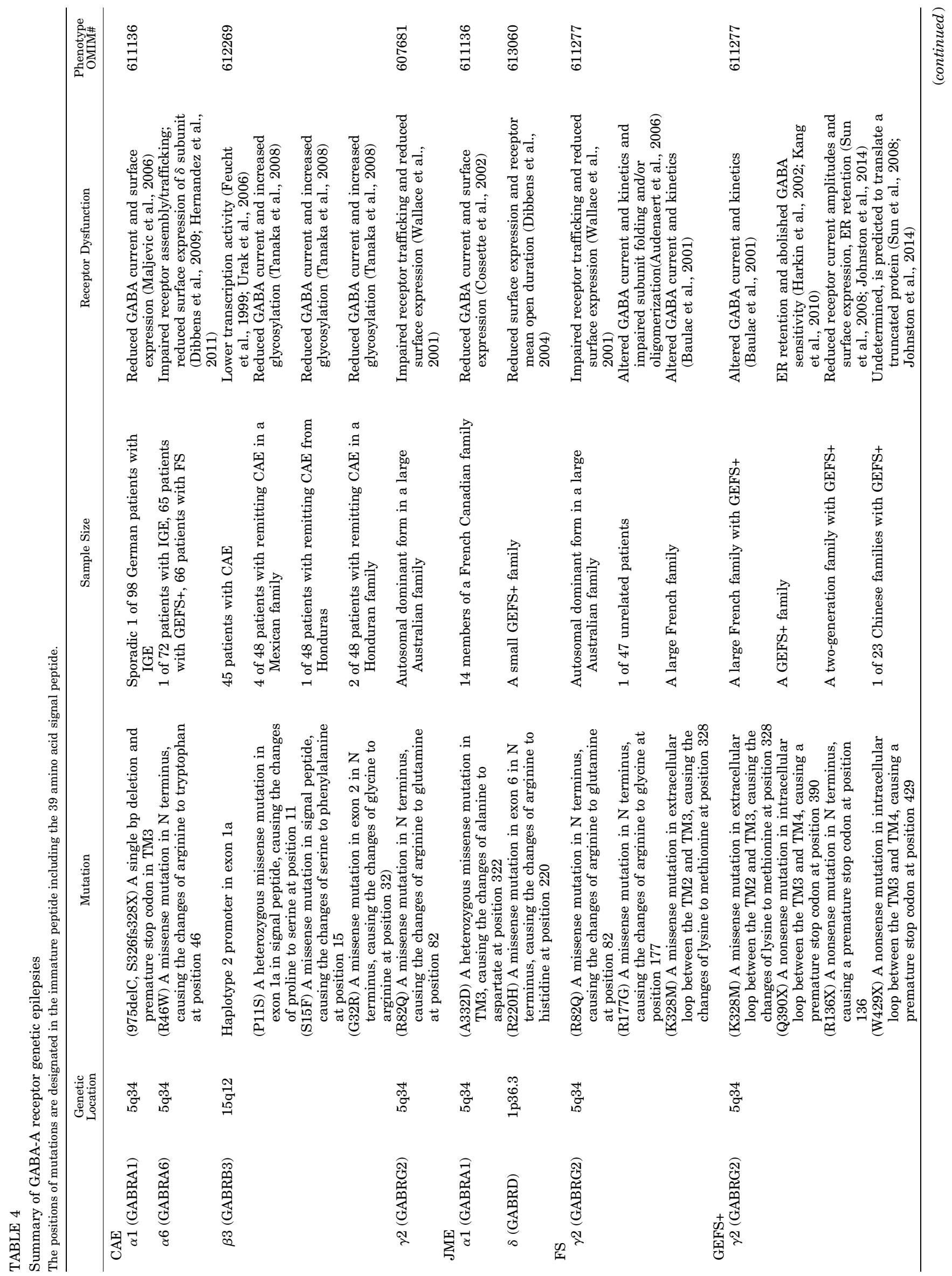

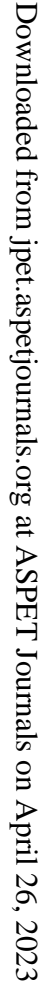


1999 (Feucht et al., 1999). Urak et al. (2006) performed a mutation screening of GABRB3 of 45 patients with CAE and found 13 single nucleotide polymorphisms and 4 haplotypes in the haplotype 2 region of the GABRB3 promoter. Lowered transcriptional activity of this region is highly associated with CAE (Feucht et al., 1999; Urak et al., 2006). Thus, diminished expression of the GABRB3 gene could be a possible cause for the development of CAE.

Missense mutations (P11S, S15F, and G32R) in GABRB3 were found in families with remitting CAE (Tanaka et al., 2008). P11S and S15F are heterozygous mutations in the exon 1a that encodes the signal peptide of the GABRB3. The P11S mutation was found in four affected subjects of a twogeneration Mexican family, and the $\mathrm{S} 15 \mathrm{~F}$ was found in one family from Honduras. G32R is a heterozygous mutation in the exon 2 of GABRB3 found in four affected persons of a two-generation Honduran family. Further investigation revealed that G32R mutation causes a partial shift of $\alpha \beta 3 \gamma 2 \mathrm{~L}$ receptors to $\alpha \beta 3$ and $\beta 3$ receptors and a reduction in macroscopic current density (Gurba et al., 2012). HEK293T cells expressing GABA-A receptors with these mutations have reduced GABA-A receptor current density attributed to hyperglycosylation in the in vitro translation and translocation system. Results suggest that elevated glycosylation in the mutant exon $1 \mathrm{a}$ and exon 2 may contribute to CAE by interfering with the maturation and trafficking of GABA-A receptors and by affecting receptor function. Mutation screening performed in 183 French Canadian individuals with IGE, including 88 with CAE, also found nine single nucleotide polymorphisms and the P11S missense mutation in GABRB3 (Lachance-Touchette et al., 2010). However, another study demonstrated that no mutations in the exon 1a promoter of GABRB3 were found in 780 German patients with IGE, including 250 with CAE (Hempelmann et al., 2007). Therefore, the association of GABRB3 with CAE is still under debate.

Mutations of $\gamma 2$ Subunit. The $\gamma$-containing GABA-A receptors are the main mediators of fast inhibitory transmission through phasic current inhibition in the synaptic sites (Sieghart and Sperk, 2002; Farrant and Nusser, 2005; Olsen and Sieghart, 2009). The $\gamma$ subunit is required for the formation of the binding site for benzodiazepines. In addition, it is also important for the clustering of the GABA-A receptor subtypes in the postsynaptic sites (Essrich et al., 1998; Fang et al., 2006). Mutations in the gene encoding the $\gamma$ subunit of GABA-A receptors (GABRG) have been associated with the pathogenesis of epilepsy; mostly FS and GEFS+. The first evidence linking GABA-A receptor subunit genes with epilepsy was reported in 2001. GABRG2 was the first identified GABA-A receptor subunit gene that is involved in IGE (Baulac et al., 2001). More evidence was subsequently discovered supporting the association between genetic epilepsies and GABA-A receptor subunit genes. A missense mutation in GABRG2 found in a large French family with GEFS+ phenotype is caused by a substitution of a positively charged lysine residue for a neutral methionine (K328M) in the extracellular loop between the TM2 and TM3 of GABRG2. The recombinant receptors with this mutant $\gamma 2 \mathrm{~K} 328 \mathrm{M}$ subunit expressed in Xenopus laevis oocytes have significantly lower amplitudes of GABA-evoked currents, indicating impaired receptor function (Baulac et al., 2001). Receptors with $\gamma 2_{\mathrm{K} 328 \mathrm{M}}$ 
subunit expressed in cultured rat hippocampal neurons displayed an accelerated decay time constant of miniature inhibitory postsynaptic currents (mIPSCs). In addition, mutant $\gamma 2_{\mathrm{K} 328 \mathrm{M}}$ receptors had decreased frequency of mIPSCs and enhanced membrane diffusion of receptors after a 1-hour exposure to elevated temperatures, which was not observed in WT receptors, suggesting a reduced number of functional inhibitory synapses and compromised GABAergic transmission (Bouthour et al., 2012). These could be a novel mechanism involved in the pathology of FS.

Two nonsense mutations (R136X and W429X) in GABRG2 were identified in a two-generation family with GEFS + and in 1 of 23 Chinese families with GEFS +, respectively (Sun et al., 2008; Johnston et al., 2014). The R136X mutation in the GABRG2 reduces receptor current amplitudes and surface expression with greater intracellular retention when $\gamma 2_{\mathrm{R} 136 \mathrm{X}}$ subunits were heterologously expressed in HEK293T cells with the $\alpha 1$ and $\beta 2$ subunits since the mutant $\gamma 2_{\mathrm{R} 136 \mathrm{X}}$ subunit did not allow the assembly of functional receptors. No dominant negative suppression effects from the mutant $\gamma 2_{\mathrm{R} 136}$ subunits on the WT receptors were noticed. The W429X is located in the extracellular loop between the TM3 and TM4 of GABRG2. It generates a premature translation termination codon and is predicted to translate a truncated protein.

A novel frameshift mutation in the GABRG2 was also identified in a family with GEFS+ (Tian et al., 2013). A cytosine nucleotide deletion in the last exon of GABRG2 results in a $\gamma 2 \mathrm{~S}_{\mathrm{S} 443 \mathrm{delC}}$ subunit with a modified and elongated carboxy-terminus. $\gamma 2_{\mathrm{S} 443 \mathrm{delC}}$ subunits, which are larger than WT $\gamma 2$ subunits when translated, displayed higher retention in the ER and lower membrane expression. Electrophysiological characterization revealed significantly decreased peak GABA-evoked currents in HEK293T cells, showing GABRG2 haploinsufficiency.

Q390X, a nonsense mutation in the intracellular loop between the TM3 and TM4 of the GABRG2 was found in patients with GEFS + , FS, and DS. This mutation introduces a premature stop codon at Q390 in the immature protein. $X$. laevis oocytes expressing recombinant receptors with a mutant $\gamma 2_{\mathrm{Q} 390 \mathrm{X}}$ subunit showed diminished response to GABA and retention in the intracellular compartment, which are also found in HEK293T cells expressing receptors with a mutant $\gamma 2_{\mathrm{R} 136 \mathrm{X}}$ subunit (Harkin et al., 2002). Mutant $\gamma 2_{\mathrm{R} 136 \mathrm{X}}$ subunits accumulated and formed high-molecular mass aggregation rapidly and showed longer half-life and slower degradation compared with WT subunits in several cell lines, including HEK293T, COS-7, and Hela cells, and in cultured rat cortical neurons (Kang et al., 2010). The accumulation and aggregation of misfolded or truncated proteins are commonly observed in neurodegenerative diseases. However, Kang et al. (2010) showed that the aggregates are also associated with genetic epilepsies. The Gabrg2 $2^{+/ Q 390 X}$ knockin mouse, developed as an animal model for severe human genetic epileptic encephalopathy, displayed spontaneous generalized tonicclonic seizures and reduced viability. In addition, impaired inhibitory neurotransmission, including reduced amplitude and frequency of GABAergic mIPSCs and accumulation of mutant $\gamma 2_{\mathrm{Q} 390 \mathrm{X}}$ subunits, were also found in this mouse. The aggregation of mutant $\gamma 2_{\mathrm{Q} 390 \mathrm{X}}$ subunits initiated caspase 3 activation and cell death in the mouse cerebral cortex (Kang et al., 2015). Their results revealed that genetic epilepsies and neurodegenerative diseases may share relevant pathologic pathways and therapies.

A missense mutation (R82Q) in the GABRG2 was found in an Australian family and results in an autosomal dominant inherited form of CAE and FS (Wallace et al., 2001; Hancili et al., 2014). Arginine 82, located in the high-affinity benzodiazepine-binding region, abolishes diazepam-potentiated currents in recombinant receptors expressed in $X$. laevis oocytes but does not affect $\mathrm{Zn}^{2+}$ sensitivity. Receptors with the mutant $\gamma 2$ subunit $\left(\alpha 3 \beta 3 \gamma 2_{\mathrm{R} 82 \mathrm{Q}}\right)$ expressed in COS-7 cells display impaired receptor trafficking and reduced membrane expression due to impaired assembly into pentamers. Furthermore, ER retention and degradation leads to abnormal receptor function when $\alpha 1 \beta 2 \gamma 2_{\mathrm{R} 82 \mathrm{Q}}$ receptors were expressed in HEK293T cells (Wallace et al., 2001; Kang and Macdonald, 2004; Frugier et al., 2007; Huang et al., 2014). $\gamma 2_{\mathrm{R} 82 \mathrm{Q}}$ receptors expressed in cultured rat hippocampal neurons and COS-7 cells show increased clathrin-mediated dynamin-dependent endocytosis, hindering their detection on the cell membrane (Chaumont et al., 2013). Animal studies revealed that $\gamma 2 \mathrm{~S}_{\mathrm{R} 82 \mathrm{Q}}$ mice displayed enhanced cortical spontaneous single-cell activity, membrane potential shift, and variance of stimulus-evoked cortical responses after pentylenetetrazol injection, supporting the focus on the cortical region in the pathology of absence epilepsy (Tan et al., 2007; Witsch et al., 2015). A splice site mutation in intron 6 of the GABRG2 was also found in patients with idiopathic absence epilepsies, CAE, and FS. This mutation is predicted to translate a nonfunctional protein and may be involved in the pathophysiology of CAE and FS (Kananura et al., 2002).

A missense mutation (R177G) in the GABRG2 was reported in patients with FS, GEFS+, and CAE (Audenaert et al., 2006). The mutation, located in the benzodiazepine allosteric site, substitutes a highly conserved arginine with glycine at position 177 in the immature peptide. Receptors with mutant $\gamma 2 \mathrm{~L}_{\mathrm{R} 177 \mathrm{G}}$ subunit expressed in HEK293T cells conferred faster current desensitization and decreased sensitivity to diazepam. The disruption of the benzodiazepine binding site could be the reason for the diminished response to benzodiazepine drugs and abnormal receptor function and may contribute to the disinhibition of the brain. $\gamma 2 \mathrm{~L}_{\mathrm{R} 177 \mathrm{G}}$ has been demonstrated to have decreased GABA sensitivity and surface expression due to the retention of receptors in the ER. $\gamma 2 \mathrm{~L}_{\mathrm{R} 177 \mathrm{G}}$ subunits also showed impaired subunit folding and/or oligomerization and could interrupt intrasubunit salt bridges and, thereby, have destabilized secondary and tertiary structure (Todd et al., 2014).

A missense mutation (P83S) in the GABRG2 was found in patients with idiopathic generalized epilepsies in a French Canadian family (Lachance-Touchette et al., 2011). The mutation, which showed a high degree of penetrance, is caused by the change of the proline 83 residue of the immature protein to a serine in a region that affects benzodiazepine binding on the extracellular ligand-binding domain. Unlike other missense mutations found in the GABRG2 gene, functional analysis of the receptors revealed that $\gamma 2_{\mathrm{P} 83 \mathrm{~S}}$ expressed in HEK293 cells does not alter the surface expression or the receptor sensitivity to $\mathrm{Zn}^{2+}$ or benzodiazepine when coexpressed with $\alpha 1$ and $\beta 2$ subunits. Further experiments are needed to elucidate whether an appreciable phenotype can be observed in the receptors with this mutant when assembling with other subunits.

A nonsense mutation (Q40X) in the GABRG2 was found in dizygotic twin girls with DS and their phenotypically healthy 
father in a Japanese family (Ishii et al., 2014). The mutation causes premature termination codons at position 40 of the GABRG2 molecule. The inward currents and current density of receptors with homozygous $\gamma 2_{\mathrm{Q} 40 \mathrm{X}}$ mutation expressed in HEK293T cells in response to GABA were intermediate between WT and heterozygous $\alpha 1 \beta 2 \gamma 2_{\mathrm{Q} 40 \mathrm{X}}$ GABA-A receptors, showing the haploinsufficiency effects of mutant $\gamma 2_{\mathrm{Q} 40 \mathrm{X}}$. In addition, cells expressing this mutant subunit have abnormal intracellular trafficking and impaired axonal transport of $\alpha 1$ and $\beta 2$ subunits.

Mutations of $\boldsymbol{\delta}$ Subunit. The $\delta$-containing GABA-A receptors primarily control the baseline neuronal network excitability through shunting and tonic inhibition. Mutations in the GABRD are thought to be involved in the pathology of epilepsy (Dibbens et al., 2004; Feng et al., 2006). To date, three point mutations (E177A, R220C, and R220H) of GABRD have been described in patients with idiopathic generalized epilepsies (a cohort study with 72 unrelated patients with IGE, 65 unrelated patients with GEFS+, and 66 unrelated patients with FS). Two missense mutations, E177A and R220C, located in the extracellular N terminus of the $\delta$ subunit were identified in a small GEFS+ family (Dibbens et al., 2004). E177 is located immediately adjacent to one of the two cysteines that form a disulfide bond, the signature feature of the cys-loop family of ligand-gated ion channels, and the R220 is positioned between the cys-loop and the first TM. In HEK293T cells, recombinant $\alpha 1 \beta 2 \mathrm{~S} \delta$ GABA-A receptors expressing E177A and $\mathrm{R} 220 \mathrm{H}$ mutations displayed decreased GABA sensitivity and increased neuronal excitability. Further investigation revealed that human recombinant $\alpha 4 \beta 2 \delta$ GABA-A receptors with E177A and $\mathrm{R} 220 \mathrm{H}$ variants have significantly reduced receptor surface expression and altered channel gating frequency, resulting in impaired inhibitory neurotransmission. In addition, mutations in the main cytoplasmic loop of the $\delta$ subunit result in interrupted receptor trafficking and decreased surface expression in recombinant HEK293 cells (Bracamontes et al., 2014). Since $\delta$-containing GABA-A receptors localize exclusively to extrasynaptic membranes and control tonic inhibition by continuously regulating the basal tone of inhibition when activated by GABA, alteration of features such as gating frequency or GABA sensitivity caused by mutations in $\delta$ subunit genes may contribute to the idiopathic generalized epilepsies.

Other GABA Receptor Subunit Mutations. A mutation in GABRA6 (R46W) was found in a patient with CAE (Dibbens et al., 2009; Hernandez et al., 2011). This mutation, caused by the substitution of arginine for tryptophan at position 46 , is located in the $\mathrm{N}$-terminal extracellular domain of the $\alpha 6$ subunit. Notably, R46 is a highly conserved residue identified from humans to Drosophila melanogaster and Caenorhabditis elegans. R46W impaired receptor assembly/trafficking and gating in both $\alpha 6_{\mathrm{R} 46 \mathrm{w}} \beta 2 \gamma 2 \mathrm{~L}$ and $\alpha 6_{\mathrm{R} 46 \mathrm{~W}} \beta 2 \delta$ recombinant receptors expressed in $X$. laevis oocytes. Surface expression of $\delta$ subunits was also decreased in R46W, showing a trend similar to that of a study reported earlier that a dramatic decrease of cerebellar $\delta$ subunit protein in $\alpha 6$ knockout mice (Jones et al., 1997). These results suggest that mutations in GABRA6 could lead to disinhibition and elevated susceptibility to genetic epilepsies due to compromised receptor function and membrane expression.

In the past decades, no genetic studies demonstrated that mutations in GABRB2 are associated with genetic epilepsies. Until recently, Srivastava et al. (2014) reported a case study in which a de novo heterozygous missense mutation of GABRB2 was found in a girl with intellectual disability and epilepsy. Their finding suggests the need for further investigation into the role of GABRB2 in the pathology of epilepsy and other neurologic disorders.

\section{Neuroendocrine Regulation of Extrasynaptic GABA-A Receptors}

NS Modulation of GABA-A Receptors and Tonic Inhibition. NSs, also referred to as neuroactive steroids, are steroids with rapid actions on neuronal excitability through the modulation of membrane receptors in the CNS (Kulkarni and Reddy, 1995; Mellon and Griffin, 2002). The terminology for "neurosteroid" and "neuroactive steroid" has been described extensively in the literature (Reddy and Rogawski, 2012). Generally, the terms NSs and neuroactive steroids are used interchangeably to refer to endogenous steroids with rapid membrane actions that were either made de novo in the brain or from peripheral sources of parent steroids that were metabolized in the brain (Baulieu, 1981; Paul and Purdy, 1992; Reddy, 2003a,b, 2009a, 2011, 2013b). Parent steroids or NS precursors (not the steroid metabolites) bind to classic steroid receptors. A brief outline of NS synthesis is described below. Cholesterol is first translocated across the mitochondrial membrane by TSPO (translocator protein $18 \mathrm{kDa}$, a key protein that controls the biosynthesis of NSs) and converted into steroid precursor pregnenolone by the cytochrome P450 side-chain cleavage enzyme in the inner membrane of mitochondria. Pregnenolone is subsequently converted into NS precursors progesterone, deoxycorticosterone, and testosterone, which go through two sequential A-ring reduction steps and are converted into three prototype endogenous NSs [allopregnanolone (AP; 3 $\alpha$-hydroxy-5 $\alpha$ pregnan-20-one), allotetrahydrodeoxycorticosterone (THDOC), and androstanediol)] by the catalysis of two key enzymes called $5 \alpha$-reductase and $3 \alpha$-hydroxysteroid oxidoreductase in the brain. These three prototype NSs, AP, THDOC, and androstanediol, have been well studied (Reddy, 2003a, 2009a, 2011; Rupprecht, 2003; Belelli and Lambert, 2005; Carver and Reddy, 2013; Brown et al., 2015; Porcu et al., 2016). THDOC potentiates both tonic current conductance and the weighted decay time of spontaneous IPSCs directly in DGGCs and cerebellar granule cells (Vicini et al., 2002; Wohlfarth et al., 2002; Stell et al., 2003). AP at low concentrations (30 and $100 \mathrm{nM}$ ) potentiates the decay time of mIPSCs in CA1 pyramidal cells (Belelli and Herd, 2003). AP also enhances GABA currents in dissociated neurons and tonic currents in hippocampal slices allosterically and directly (Carver et al., 2014; Carver and Reddy, 2016).

Ganaxolone (GX, $3 \alpha$-hydroxy-3 $\beta$-methyl-5 $\alpha$-pregnan-20-one), the $3 \beta$-methylated analog of $\mathrm{AP}$, is now being assessed in advanced clinical trials for epilepsy (Pieribone et al., 2007; Porcu et al., 2016). Like AP, GX has been shown to modulate GABA-A receptors in $X$. laevis oocytes expressing human recombinant $\alpha 1 \beta 1 \gamma 2 \mathrm{~L}$ receptors (Carter et al., 1997). Natural NSs have low bioavailability since they can be back-converted to active 3-ketone-containing progesterone metabolites (Rupprecht et al., 1993). The synthetic $3 \beta$-substituted GX provides a more promising pharmacokinetic profile as an antiepileptic drug, overcoming the limitations of lower bioavailability by preventing the oxidation of the $3 \alpha$-hydroxyl group (Carter et al., 1997). GX possesses broad-spectrum anticonvulsant activity in animal 
seizure models (Reddy and Rogawski, 2000a,b, 2010). GX is currently being evaluated in clinical trials for the treatment of epilepsy and related conditions (Nohria and Giller, 2007; Reddy and Rogawski, 2010, 2012; Bialer et al., 2015; Braat et al., 2015; Ligsay et al., 2017).

Progesterone, GX, and AP have been evaluated in clinical trials for seizure conditions (Reddy and Estes, 2016; Younus and Reddy, 2017). GX has been evaluated in more than 1300 subjects in various clinical studies in adults and children with epilepsy (Kerrigan et al., 2000; Laxer et al., 2000; Reddy and Woodward, 2004; Nohria and Giller, 2007; Pieribone et al., 2007; Sperling et al., 2017). Progesterone was evaluated as an adjunct therapy in women with epilepsy (Herzog et al., 2012). The NS AP (brexanolone) has been suggested as an intravenous therapy for refractory SE (Rosenthal et al., 2017) and postpartum depression (Kanes et al., 2017). Overall, synthetic NS analogs, which activate both synaptic and extrasynaptic GABA-A receptor-mediated tonic inhibition in the brain, may be promising compounds for the clinical development of specific seizure conditions, such as status epileptic and catamenial epilepsy.

Protein Kinase Modulation of NS-Sensitive GABA-A Receptors. Protein kinases are enzymes that can regulate the function of other proteins by phosphorylating hydroxyl groups on the proteins by which they act. Protein kinase activity influences GABA-A receptor surface expression, trafficking, chloride conductance, and sensitivity to NSs. Several GABA-A receptor subunits contain residues that can be phosphorylated by protein kinases including $\alpha 4, \beta$, and $\gamma 2$ subunits (Moss and Smart, 1996; Brandon et al., 2000). The serine residue (Ser-443) within the intracellular domain of the $\alpha 4$ subunit is phosphorylated by protein kinase C (PKC) (Abramian et al., 2010). A conserved serine residue (Ser-409 or Ser-410) of the $\beta$ subunit is phosphorylated by PKC, protein kinase A (PKA), $\mathrm{Ca}^{2+} /$ calmodulin-dependent protein kinase II (CaMKII), and cGMP-dependent protein kinase. Two additional serine residues of the $\beta$ subunit (Ser-408 and Ser-383) are also phosphorylated by PKA and CaMKII, respectively (McDonald et al., 1998; Saliba et al., 2012). Additionally, the tyrosine residues (Tyr-365 and Tyr-367) and serine residue (Ser-343) of the $\gamma 2$ subunit are also substrates of tyrosine kinase and PKC, respectively (Krishek et al., 1994; Moss et al., 1995). Phosphorylation of residues within the intracellular loops of the $\beta 3$ and $\gamma 2$ subunits maintains the surface expression of GABA-A receptors, whereas, dephosphorylation of these subunits triggers receptor internalization (Kittler et al., 2005, 2008) (Fig. 5).

Previous studies have shown that PKC activity regulates receptor function, ion conductance, and ion response to receptor modulators. Ten-minute bath application of PKC activator phorbol 12-myristate 13-acetate increases THDOCpotentiated, GABA-gated chloride currents (Leidenheimer and Chapell, 1997). Treatment with the specific PKC antagonist bisindolylmaleimide 15 minutes before and during NS administration diminishes the decay of IPSCs by NSs (Fáncsik et al., 2000). The inhibition of either PKA or PKC by intracellular dialysis significantly reduces NS $5 \beta$-pregnan$3 \alpha$-ol-20-one-mediated prolonged decay of mIPSCs in CA1 pyramidal neurons, whereas the activation of PKC has no effect on NS sensitivity (Harney et al., 2003). Phosphorylation of the serine residue of the $\beta$ subunits (Ser-383) by L-type voltage-gated $\mathrm{Ca}^{2+}$ channel-activated CaMKII leads to rapid surface expression of GABA-A receptors and enhanced tonic currents in hippocampal neurons (Saliba et al., 2012). Tenminute cotreatment with PKC inhibitor prevents THDOCupregulated phosphorylation of the $\alpha 4$ subunits and surface expression of $\alpha 4$-containing GABA-A receptors (Abramian et al., 2014). A recent study (Modgil et al., 2017) demonstrated that continuous application of $\mathrm{AP}$, but not GX, upregulates the phosphorylation and surface expression of the $\beta 3$-containing GABA-A receptors and tonic current potentiation, effects prevented by the application of PKC inhibitor 15 minutes before and during NS application.

Zinc Antagonism of NS-Sensitive GABA-A Receptors. Zinc $\left(\mathrm{Zn}^{2+}\right)$ is an essential cofactor in many cells including neurons. $\mathrm{Zn}^{2+}$ is the most abundant transition metal in the vesicles of hippocampal mossy fibers that project from the DG to the CA3 (Frederickson, 1989). During neuronal activity, vesicular $\mathrm{Zn}^{2+}$ is released synaptically from certain nerve terminals in the hippocampus (Tian et al., 2010). Excessive release of $\mathrm{Zn}^{2+}$ has been shown in epilepsy, and it can decrease the threshold of excitability and seizures (Takeda et al., 1999; Coulter, 2000; Foresti et al., 2008). $\mathrm{Zn}^{2+}$ regulation of postsynaptic targets and synaptic plasticity is shown in Fig. 6. $\mathrm{Zn}^{2+}$ modulates several ligand- and voltage-gated ion channels (Harrison and Gibbons 1994). In particular, $\mathrm{Zn}^{2+}$ attenuates GABAergic inhibition at mossy fiber synaptic varicosities that release GABA (Xie and Smart, 1991; Ruiz et al., 2004; Bitanihirwe and Cunningham, 2009). In addition, $\mathrm{Zn}^{2+}$ has been shown to negatively modulate synaptic GABA-A receptors and modify the excitability of the hippocampal network (Barberis et al., 2000). The following three distinct $\mathrm{Zn}^{2+}$ binding sites mediate its inhibition of GABA-A receptors: one site at the internal surface of the channel pore and two at the external amino terminus of the $\alpha-\beta$ interfaces. The incorporation of the $\gamma$ subunit after GABA-A receptor coassembly disrupts two of the $\mathrm{Zn}^{2+}$ binding sites, which leads to a reduced sensitivity to $\mathrm{Zn}^{2+}$ inhibition (Hosie et al., 2003). Thus, the sensitivity to $\mathrm{Zn}^{2+}$ inhibition is different between the two different GABA-A receptor subtypes ( $\delta$ containing and $\gamma$ containing) (Smart et al., 1991; Stórustovu and Ebert, 2006).

Our recent study demonstrated the $\delta$-containing receptors to be more sensitive to $\mathrm{Zn}^{2+}$ inhibition than $\gamma$-containing receptors, and $\mathrm{Zn}^{2+}$ selectively blocks NS-sensitive extrasynaptic $\delta$ GABA-A receptor-mediated tonic currents in the mouse hippocampus dentate gyrus (Carver et al., 2016). $\mathrm{Zn}^{2+}$ blocked AP potentiation of tonic currents in a concentration-dependent manner, whereas synaptic currents were unaffected. Application of $\mathrm{Zn}^{2+}$ chelator prevented the positive shift of tonic currents by $\mathrm{Zn}^{2+}$, confirming the $\mathrm{Zn}^{2+}$ blockade of AP-sensitive tonic currents. In the mouse kindling model of epilepsy, intrahippocampal infusion of $\mathrm{Zn}^{2+}$ resulted in rapid epileptiform activity and the prevention of the antiseizure activity of AP. Therefore, $\mathrm{Zn}^{2+}$ inhibition of NS-potentiated, extrasynaptic GABA-A receptors in the hippocampus has direct involvement in a variety of brain conditions, such as seizures, epileptogenesis, epilepsy, and conditions with compromised balance of excitation/inhibition. Both $\mathrm{Zn}^{2+}$ and NSs show high affinity for extrasynaptic $\delta$-containing GABA-A receptors, but their actions are distinctly opposite through the binding of different allosteric sites. Overall, $\mathrm{Zn}^{2+}$ hinders NS activation of extrasynaptic $\delta$ GABA-A receptor-mediated tonic inhibition and their ability to promote neuroprotection and inhibit seizure activity in the brain. 


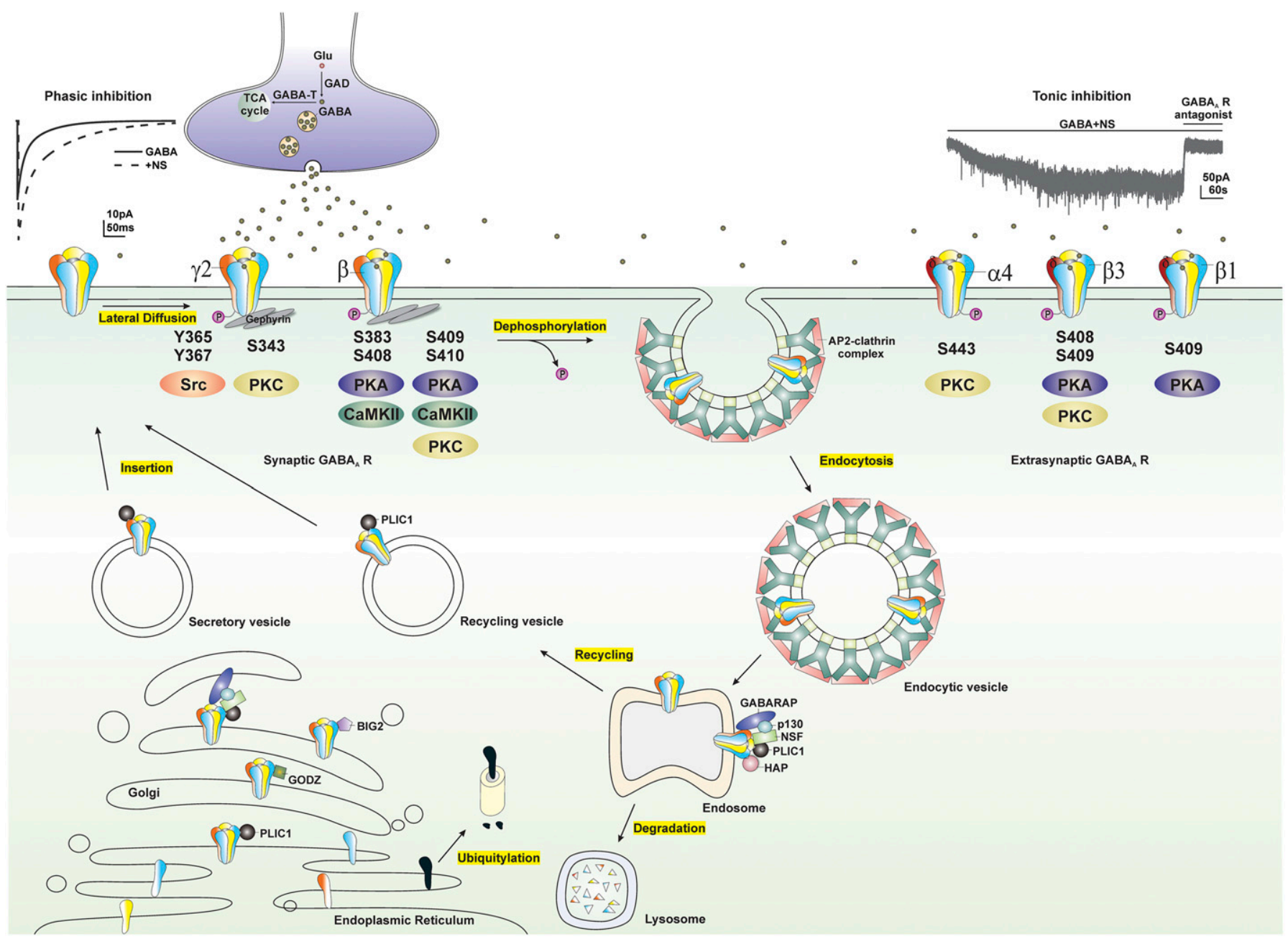

Fig. 5. Modulation of extrasynaptic GABA-A receptors (GABA-ARs) trafficking by phosphorylation. GABA-ARs composed of $\alpha, \beta$, and $\gamma$ subunits are mostly clustered at synaptic sites, whereas GABA-ARs composed of $\alpha, \beta$, and $\delta$ subunits are clustered at extrasynaptic sites. GABA-ARs are assembled in the ER, matured in the Golgi, secreted, and inserted into the plasma membrane. Synaptic GABA-ARs, reaching their destination through lateral diffusion in the cell membrane, are activated by presynaptic release of GABA and produce fast and transient phasic inhibition, whereas continuous activation of extrasynaptic GABA-ARs by ambient GABA generates persistent tonic inhibition that sets the baseline of neuronal inhibition. NSs at submicromolar concentrations potentiate both phasic and tonic inhibition through allosteric modulation of synaptic and extrasynaptic GABA-ARs, respectively. GABA-AR subunits, including $\alpha 4, \beta$, and $\gamma 2$ subunits, contain residues that can be phosphorylated by various protein kinases. Phosphorylation of residues within GABA-ARs not only regulates receptor function but maintains their surface expression. Dephosphorylation of these subunits triggers receptor internalization through adaptor protein 2 (AP2)-clathrin complex-dependent endocytosis. Internalized receptors are subsequently transported to the endosomal system, where they can be either recycled to the surface or degraded in the lysosomes. GABA-AR trafficking is facilitated by a variety of protein-protein interactions. BIG2, a brefeldin A-inhibited GDP/GTP exchange factor, binds to the intracellular loop of $\beta$ subunits and is involved in the trafficking of receptors; GABARAP, a GABA-AR-associated protein, interacts with the $\gamma 2$ subunit of GABA-ARs and might facilitate receptor insertion into the cell membrane; GABA-T, GABA transaminase; GODZ, a Golgi-specific DHHC zinc finger domain protein, mediates post-translational palmitoylation; HAP, a Huntingtin-associated protein, interacts with the $\beta$ subunit of GABA-ARs and facilitates receptor recycling to the cell membrane; GAD, glutamate decarboxylase; NSF, a N-ethylmaleimide-sensitive factor, interacts with GABARAP and p130 and plays a crucial role in intracellular transport; p130, a phospholipase, shares the same binding site on the $\gamma 2$ subunit with the GABARAP; PLIC-1, a ubiquitin-like protein, increases receptor stability and enhances membrane insertion of receptors.

Insights from Transgenic Models on Tonic Inhibition. To elucidate the distinctive pharmacological and functional properties and the role of the $\delta$ subunit in brain disorders, a strain of mice globally lacking the $\delta$ subunit [GABA-A receptor $\delta$ subunit knockout (DKO)] of GABA-A receptors was introduced in 1999 (Mihalek et al., 1999). Initial pharmacological and behavioral characterizations revealed the DKO mice have significantly lower binding affinity for muscimol, a GABA binding agonist with high affinity to $\delta$-containing GABA-A receptors, and a faster decay of mIPSCs and inhibitory postsynaptic potentials than that of WT mice. In addition, DKO mice show significantly decreased sleep time in response to alphaxolone, a NS and general anesthetic, diminished sensitivity to anxiolytic drugs examined by elevated plus-maze assay, diminished GX-facilitated exacerbation of pentylenetetrazol-induced absence seizure, and higher vulnerability to the chemoconvulsants seizures caused by GABA-A receptor antagonists. Their results suggest that deficiency of the $\delta$ subunit of the GABA-A receptors leads to a significant attenuation in the sensitivity to behavioral actions of NSs, which may contribute to a higher degree of seizure susceptibility (Mihalek et al., 1999; Spigelman et al., 2002, 2003; Porcello et al., 2003; Chandra et al., 2010). 


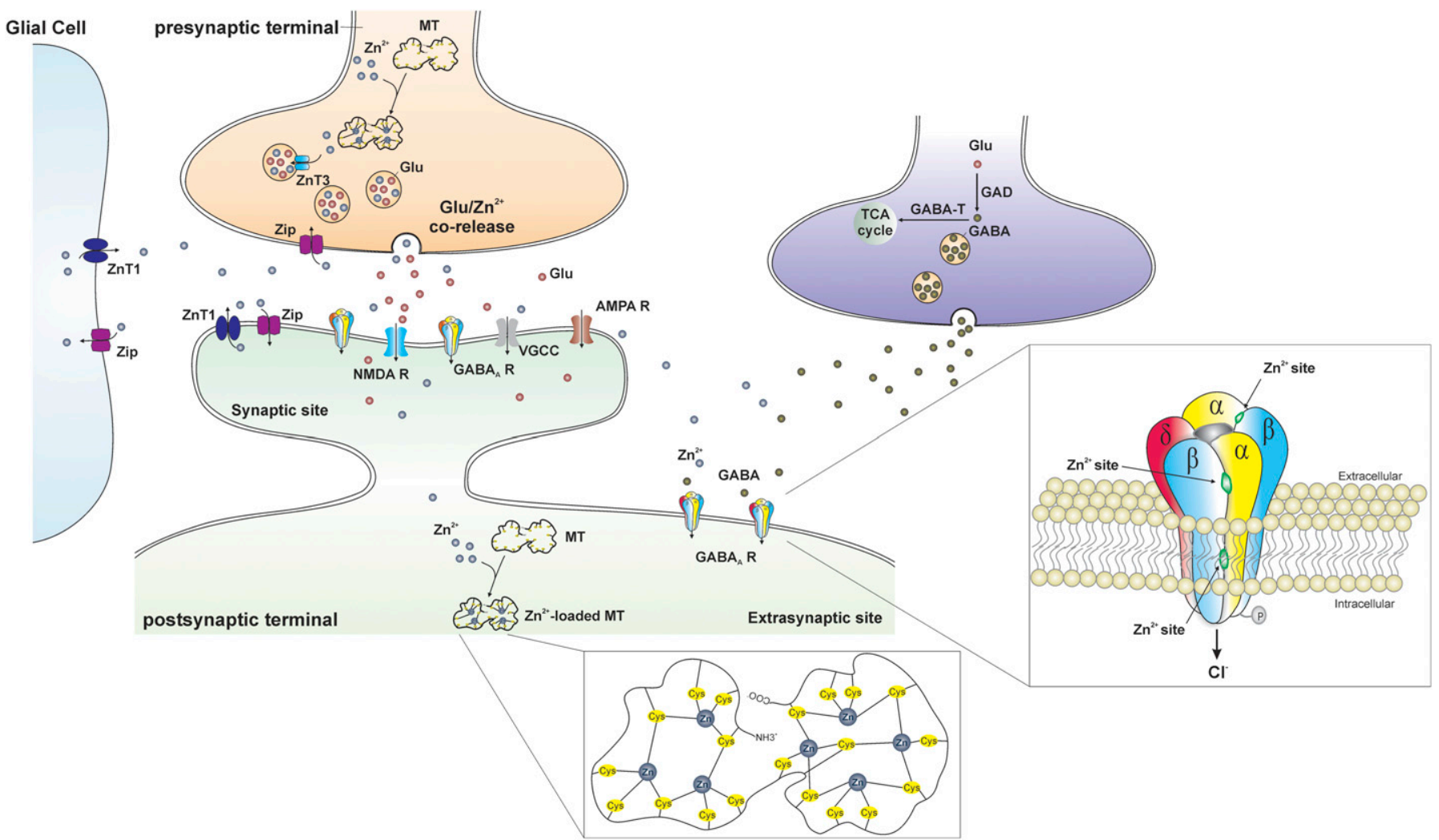

Fig. 6. Trafficking of $\mathrm{Zn}^{2+}$ at the gluzinergic synapse. In the gluzinergic terminal, the availability of free $\mathrm{Zn}^{2+}$ is regulated by metallothioneins (MTs), the primary intracellular $\mathrm{Zn}^{2+}$-buffering proteins. The MT is a dumbbell-shaped, cysteine (Cys)-rich protein composed of two domains in which 7 zinc atoms are tetrahedrally bound to 20 cysteines (inset, middle). The $\mathrm{Zn}^{2+}$ transporter $(\mathrm{ZnT})$ and Zip proteins are also involved in the regulation of $\mathrm{Zn}^{2+}$ in the cytoplasm. $\mathrm{ZnT}$ proteins promote $\mathrm{Zn}^{2+}$ efflux and vesicular uptake to decrease the amount of intracellular $\mathrm{Zn}^{2+}$, whereas $\mathrm{Zip}$ proteins facilitate the influx of extracellular $\mathrm{Zn}^{2+}$ into neurons and glial cells to increase the concentration of intracellular $\mathrm{Zn}^{2+}$. Free $\mathrm{Zn}^{2+}$ is transferred into synaptic vesicles through the ZnT3 proteins and stored with glutamate. During normal neurotransmission, $\mathrm{Zn}^{2+}$ - and glutamate-containing vesicles fuse with cell membrane and corelease $\mathrm{Zn}^{2+}$ and glutamate into the synaptic cleft. There are a variety of postsynaptic targets that $\mathrm{Zn}^{2+}$ can act on, including $N$-methyl-D-aspartate receptors (NMDA Rs), $\alpha$-amino-3-hydroxy-5-methyl-4-isoxazolepropionic acid receptors (AMPA Rs), voltage-gated calcium channels (VGCCs), GABA-ARs, and a number of other channels, transporters, and receptors. Three distinct $\mathrm{Zn}^{2+}$ binding sites mediate its inhibition of extrasynaptic $\delta$-containing GABAARs (inset, right): one site at the internal surface of the channel pore and two at the external amino terminus of the $\alpha-\beta$ interfaces.

The $\delta$-specific selectivity for NS modulation is further confirmed by electrophysiological studies demonstrating suppressed responses to THDOC modulation such as decreased spontaneous IPSCs in cerebellar granule cells and decreased tonic conductance in DGGCs in the DKO mouse model (Vicini et al., 2002; Wohlfarth et al., 2002; Stell et al., 2003). In addition, attenuated response to AP potentiation of GABAergic and tonic currents is also evident in mice bearing a targeted deletion of the $\delta$ subunit, underscoring the role of $\delta$-containing GABA-A receptors for NS activity (Carver et al., 2014; Carver and Reddy, 2016). Reduced response to gaboxadol (THIP)-induced hypnotic activity is also reported in $\delta$-deficient mice, suggesting the requirement of $\delta$-containing GABA-A receptors in the action of THIP, a preferential agonist of $\delta$-containing GABA-A receptors at low concentrations (Boehm et al., 2006; Meera et al., 2011).

In the composition of the receptor subunits, the deletion of the $\delta$ subunit accompanied the decreased expression of the $\alpha 4$ subunit and the increased expression of the $\gamma 2$ subunit in brain regions that normally contained the $\delta$ subunit, such as hippocampus and thalamus (Korpi et al., 2002; Peng et al., 2002). The results from electrophysiology, animal knockout models, and immunohistochemistry specific to DGGCs indicate that $\alpha 4 \beta 2 \delta$ GABA-A receptors are the major receptors located in extrasynaptic sites and are responsible for tonic current inhibition in DGGCs (Sun et al., 2004; Chandra et al., 2006; Herd et al., 2008). The $\alpha 5$ subunit contributes to the remaining tonic currents in DGGCs (Glykys et al., 2008; Carver and Reddy, 2013). The $\delta$-containing GABA-A receptors are highly sensitive to $\mathrm{Zn}^{2+}$ and the $\mathrm{Zn}^{2+}$-reduced decay time and amplitude of evoked IPSCs in DGGCs from WT is lacking in DKO mice. Recently, we have uncovered that $\mathrm{Zn}^{2+}$ showed a concentration-dependent blockade of AP-potentiated tonic currents in DGGCs. Moreover, $\mathrm{Zn}^{2+}$ inhibition of AP-sensitive tonic currents is absent in DKO mice (Wei et al., 2003; Carver et al., 2016). Animal studies further revealed that $\mathrm{Zn}^{2+}$ prevents the antiseizure activity of AP in epileptic mice, suggesting that $\mathrm{Zn}^{2+}$ blockade of NS-sensitive, extrasynaptic $\delta$-containing GABA-A receptors in the hippocampus possesses implications in a variety of neuronal hyperexcitability disorders like SE and epilepsy.

\section{Therapeutic Insights of Tonic Inhibition in Epilepsy}

Extrasynaptic GABA-A receptors are involved in the pathophysiology of certain brain conditions, such as catamenial 
epilepsy, SE, and other neuroendocrine disorders (Belelli and Lambert 2005; Brickley and Mody, 2012; Reddy, 2013a,b, 2016). Consequently, these receptors are emerging as novel targets for excitability disorders (Reddy and Estes, 2016). Substantial evidence suggests that NS-sensitive, extrasynaptic GABA-A receptors play a critical role in the pathophysiology of catamenial epilepsy, a menstrual cycle-related seizure clustering in women with epilepsy (Reddy et al., 2001, 2012; Reddy and Rogawski, 2001, 2012; Reddy, 2009a, 2014, 2016a, 2017; Wu et al., 2013). Although this condition has been documented for millennia, there is currently no effective treatment of catamenial seizures, leaving many women and their families desperate for answers. Recently, a catameniallike seizure exacerbation has been clearly demonstrated in mice with targeted ablation of extrasynaptic $\delta \mathrm{GABA}-\mathrm{A}$ receptors in the brain (Clossen and Reddy, 2017). This has substantially bolstered the role of tonic inhibition in catamenial epilepsy (Reddy, 2016a). In essence, extrasynaptic $\delta \mathrm{GABA}-\mathrm{A}$ receptors are strikingly upregulated during perimenstruallike neuroendocrine milieu (Gangisetty and Reddy, 2010; Carver et al., 2014). Consequently, there is greater antiseizure efficacy of NSs in catamenial models because $\delta$ GABA-A receptors confer enhanced NS sensitivity and greater seizure protection. Therefore, this molecular mechanism of tonic inhibition as the major regulator of the catamenial seizures is providing a strong platform for "neurosteroid replacement therapy," a pulse therapy with low doses of synthetic NS agents that may effectively control catamenial seizures without hormonal side effects (Reddy and Rogawski, 2009).

NS levels are reduced during SE, a neurologic emergency characterized by continuous seizure activity or multiple seizures without regaining consciousness for more than 30 minutes (Meletti et al., 2017). Benzodiazepines such as lorazepam and midazolam are the primary anticonvulsants for SE, but some patients do not respond to these treatments, a condition referred to as refractory SE (Reddy and Reddy, 2015). Benzodiazepines target synaptic GABA-A receptors but have little effect on extrasynaptic isoforms, which are responsible for tonic inhibition (Reddy et al., 2015). There are many theories, but functional inactivation of synaptic GABA-A receptors via active internalization appears to be a lead physiologic mechanism by which benzodiazepine resistance emerges in SE (Naylor et al., 2005; Reddy and Reddy, 2015). Therefore, NS agents such as AP and its synthetic analogs, which potentiate both phasic and tonic current, have been proposed as better anticonvulsant agents for the treatment of SE (Briyal and Reddy, 2008; Reddy, 2009b; Rogawski et al., 2013). Clinical evaluation of AP is in progress to test this therapeutic premise (Rosenthal et al., 2017; Vaitkevicius et al., 2017).

Synthetic NSs are proposed as novel anticonvulsant antidotes for chemical intoxication caused by organophosphate (OP) pesticides and nerve agents like sarin and soman (Reddy, 2016b). Benzodiazepines, such as diazepam, are the current anticonvulsants of choice for controlling nerve agent-induced seizures, SE, and brain injury. Benzodiazepines can control acute seizures when given early, but they are ineffective for delayed treatment of SE after nerve agent exposure (Reddy and Reddy, 2015). NS-sensitive extrasynaptic GABA-A receptors are minimally impacted by OP intoxication. Thus, anticonvulsant NSs may produce more effective protection than benzodiazepines against a broad spectrum of chemical agents, even when given late after nerve agent exposure, because NSs can activate both synaptic and extrasynaptic GABA-A receptors and thereby can produce maximal inhibition (Carver and Reddy, 2016). An intramuscular GX product is being developed as an anticonvulsant antidote for nerve agents. A NS therapy with a synthetic NS such as GX has been found to more protective than midazolam for controlling persistent SE and neuronal damage caused by OP pesticides and nerve agents (Reddy, 2016b). Although NSs show great promise in the treatment of SE, none are currently approved by the Food and Drug Administration for clinical use.

Some endogenous NSs, such as dehydroepiandrosterone sulfate (DHEAS), are negative modulators of GABA-A receptors and can cause proconvulsant actions (Majewska et al., 1990; Reddy and Kulkarni, 1998). It is likely that such actions have clinical implications in certain physiologic and pathologic conditions (Galimberti et al., 2005; Reddy, 2006, 2009a; b; Pack et al., 2011). It is hypothesized that the increase in the frequency of onset of seizures during the process of adrenarche, which is associated with a massive increase in DHEAS production, is caused by the ability of DHEAS to block GABA-A receptors. However, it remains unclear whether DHEAS can negatively modulate extrasynaptic GABA-A receptors in the brain. In addition, there are developmental changes in hippocampal extrasynaptic GABA-A receptors during puberty with significant impact on cognitive function (Shen et al., 2010; Reddy, 2014).

\section{Conclusions and Perspectives}

Recent advances in our knowledge of GABA-A receptor genetics provide great opportunities to further explore the underlying mechanisms of epileptogenesis and to discover effective interventions for the prevention, control, and cure of epilepsy. By comprehensively classifying and mapping the relevance of genetic epilepsies and gene mutations, the roles of GABA-A receptor function and subunit composition in the pathophysiology of epilepsy can be elucidated. In combination with advancing our understanding of the interactions between NSs and GABA-A receptors and their impacts on inhibitory neuronal transmission, more promising therapeutic implications may be disclosed. Factors that result in the imbalance of inhibition and excitation in the brain are associated with the occurrence of epilepsy. Specific GABAergic genetic aberrations lead to some of the classic epileptic syndromes. Dysregulation of neuronal activity and changes in the composition and function of GABA-A receptors contribute to the development of epilepsy.

Mutations in $\delta$ subunit are found in patients with genetic epilepsies. Mice lacking the $\delta$ subunit of GABA-A receptors have attenuated sensitivity to NSs in behavioral outcomes and electrophysiological characterizations, contributing to higher seizure vulnerability. Extrasynaptic $\delta$-containing GABA-A receptors produce tonic currents to maintain the baseline of inhibition in the brain when activated by specific agonists. NSs interact with extrasynaptic GABA-A receptors and potentiate tonic inhibition through multiple mechanisms, providing potential therapeutics for hyperexcitable brain disorders such as SE, epileptogenesis, and epilepsy. The clinical trials of NSs for various conditions has been described previously (Reddy and Estes, 2016). The discovery of an extrasynaptic mechanism is providing a strong platform for novel therapies such as NS replacement therapy for catamenial epilepsy (Reddy, 2016a). 
NSs have been proposed as more effective anticonvulsants than benzodiazepines for controlling refractory seizures, such as persistent SE, that occur after OP intoxication and nerve agent exposure (Reddy, 2016b). Future work will certainly consolidate our knowledge in genetic epilepsies and facilitate the improvement of selective interventions for modulating the neuronal network under physiologic and pathologic conditions.

\section{Highlights}

- GABA-A receptors play a critical role in epilepsy and many brain disorders.

- Changes in the abundance or distribution of GABA-A receptors affect the drug response.

- Extrasynaptic GABA-A receptors are intricately involved in regulating the network excitability and behavior.

- Mutations in $\delta$ GABA-A receptors lead to diminished tonic inhibition and epileptic seizures.

- Neuroendocrine control of extrasynaptic GABA-A receptors provides additional regulation of tonic inhibition in the brain.

- The tonic inhibition is a unique new mechanism in epilepsy, status epilepticus, and certain brain disorders.

\section{Authorship Contributions}

Wrote or contributed to the writing of the manuscript: Chuang, Reddy.

\section{References}

Abramian AM, Comenencia-Ortiz E, Modgil A, Vien TN, Nakamura Y, Moore YE, Maguire JL, Terunuma M, Davies PA, and Moss SJ (2014) Neurosteroids promote phosphorylation and membrane insertion of extrasynaptic GABA-A receptors. Proc Natl Acad Sci USA 111:7132-7137.

Abramian AM, Comenencia-Ortiz E, Vithlani M, Tretter EV, Sieghart W, Davies PA and Moss SJ (2010) Protein kinase C phosphorylation regulates membrane insertion of GABAA receptor subtypes that mediate tonic inhibition. J Biol Chem 285:41795-41805.

Audenaert D, Schwartz E, Claeys KG, Claes L, Deprez L, Suls A, Van Dyck T, Lagae L, Van Broeckhoven C, Macdonald RL, et al. (2006) A novel GABRG2 mutation associated with febrile seizures. Neurology 67:687-690.

Barberis A, Cherubini E, and Mozrzymas JW (2000) Zinc inhibits miniature GABAergic currents by allosteric modulation of GABAA receptor gating. $J$ Neurosci 20:8618-8627.

Baulac S, Huberfeld G, Gourfinkel-An I, Mitropoulou G, Beranger A, Prud'homme JF, Baulac M, Brice A, Bruzzone R, and LeGuern E (2001) First genetic evidence of GABA(A) receptor dysfunction in epilepsy: a mutation in the gamma2-subunit gene. Nat Genet 28:46-48.

Baulieu EE (1981) Steroid hormones in the brain: several mechanisms?, in Steroid Hormone Regulation of the Brain (Fuxe F, Gustafsson JA, and Wetterberg L eds) pp 3-14, Pergamon Press, Oxford.

Belelli D and Herd MB (2003) The contraceptive agent provera enhances GABA(A) receptor-mediated inhibitory neurotransmission in the rat hippocampus: evidence for endogenous neurosteroids? J Neurosci 23:10013-10020.

Belelli D and Lambert JJ (2005) Neurosteroids: endogenous regulators of the GABA (A) receptor. Nat Rev Neurosci 6:565-575.

Bialer M, Johannessen SI, Levy RH, Perucca E, Tomson T, and White HS (2015) Progress report on new antiepileptic drugs: a summary of the Twelfth Eilat Conference (EILAT XII). Epilepsy Res 111:85-141.

Bianchi MT and Macdonald RL (2002) Slow phases of GABA(A) receptor desensitization: structural determinants and possible relevance for synaptic function. J Physiol 544:3-18.

Bianchi MT and Macdonald RL (2003) Neurosteroids shift partial agonist activation of $\operatorname{GABA}(\mathrm{A})$ receptor channels from low- to high-efficacy gating patterns. $J \mathrm{Neu}$ rosci 23:10934-10943.

Bitanihirwe BK and Cunningham MG (2009) Zinc: the brain's dark horse. Synapse 63:1029-1049.

Blednov YA, Jung S, Alva H, Wallace D, Rosahl T, Whiting PJ, and Harris RA (2003) Deletion of the alpha1 or beta2 subunit of GABAA receptors reduces actions of alcohol and other drugs. J Pharmacol Exp Ther 304:30-36.

Boehm SL, II, Homanics GE, Blednov YA, and Harris RA (2006) delta-Subunit containing GABAA receptor knockout mice are less sensitive to the actions of 4,5,6,7-tetrahydroisoxazolo-[5,4-c]pyridin-3-ol. Eur J Pharmacol 541:158-162.

Bouthour W, Leroy F, Emmanuelli C, Carnaud M, Dahan M, Poncer JC, and Lévi S (2012) A human mutation in Gabrg2 associated with generalized epilepsy alters the membrane dynamics of GABAA receptors. Cereb Cortex 22: 1542-1553.
Braat S, D'Hulst C, Heulens I, De Rubeis S, Mientjes E, Nelson DL, Willemsen R, Bagni C, Van Dam D, De Deyn PP, et al. (2015) The GABAA receptor is an FMRP target with therapeutic potential in fragile X syndrome. Cell Cycle 14:2985-2995. Bracamontes JR, Li P, Akk G, and Steinbach JH (2014) Mutations in the main cytoplasmic loop of the GABA(A) receptor $\alpha 4$ and $\delta$ subunits have opposite effects on surface expression. Mol Pharmacol 86:20-27.

Bradley CA, Taghibiglou C, Collingridge GL, and Wang YT (2008) Mechanisms involved in the reduction of GABAA receptor alpha1-subunit expression caused by the epilepsy mutation $\mathrm{A} 322 \mathrm{D}$ in the trafficking-competent receptor. J Biol Chem 283:22043-22050.

Brandon NJ, Delmas P, Kittler JT, McDonald BJ, Sieghart W, Brown DA, Smart TG, and Moss SJ (2000) GABAA receptor phosphorylation and functional modulation in cortical neurons by a protein kinase C-dependent pathway. J Biol Chem 275 $38856-38862$.

Brickley SG, Cull-Candy SG, and Farrant M (1999) Single-channel properties of synaptic and extrasynaptic GABAA receptors suggest differential targeting of receptor subtypes. J Neurosci 19:2960-2973.

Brickley SG and Mody I (2012) Extrasynaptic GABA(A) receptors: their function in the CNS and implications for disease. Neuron 73:23-34.

Briyal S and Reddy DS (2008) Neuroactive steroid therapy of status epilepticus in epilepsy rats. Epilepsia 49 (Suppl 7):3055.

Brown AR, Herd MB, Belelli D, and Lambert JJ (2015) Developmentally regulated neurosteroid synthesis enhances GABAergic neurotransmission in mouse thalamocortical neurones. $J$ Physiol 593:267-284.

Brown N, Kerby J, Bonnert TP, Whiting PJ, and Wafford KA (2002) Pharmacological characterization of a novel cell line expressing human alpha(4)beta(3)delta GABA (A) receptors. $\mathrm{Br}$ J Pharmacol 136:965-974.

Carter RB, Wood PL, Wieland S, Hawkinson JE, Belelli D, Lambert JJ, White HS, Wolf HH, Mirsadeghi S, Tahir SH, et al. (1997) Characterization of the anticonvulsant properties of ganaxolone (CCD 1042; 3alpha-hydroxy-3beta-methyl5alpha-pregnan-20-one), a selective, high-affinity, steroid modulator of the gamma-aminobutyric acid(A) receptor. J Pharmacol Exp Ther 280:1284-1295.

Carver CM, Chuang SH, and Reddy DS (2016) Zinc selectively blocks neurosteroidsensitive extrasynaptic $\delta$ GABAA receptors in the hippocampus. $J$ Neurosci 36: 8070-8077.

Carver CM and Reddy DS (2013) Neurosteroid interactions with synaptic and extrasynaptic GABA(A) receptors: regulation of subunit plasticity, phasic and tonic inhibition, and neuronal network excitability. Psychopharmacology (Berl) 230: 151-188.

Carver CM and Reddy DS (2016) Neurosteroid structure-activity relationships for functional activation of extrasynaptic deltaGABA-A receptors. $J$ Pharmacol Exp Ther 357:188-204

Carver CM, Wu X, Gangisetty O, and Reddy DS (2014) Perimenstrual-like hormonal regulation of extrasynaptic $\delta$-containing GABAA receptors mediating tonic inhibition and neurosteroid sensitivity. J Neurosci 34:14181-14197.

Carvill GL, Weckhuysen S, McMahon JM, Hartmann C, Møller RS, Hjalgrim H, Cook J, Geraghty E, O'Roak BJ, Petrou S, et al. (2014) GABRA1 and STXBP1: novel genetic causes of Dravet syndrome. Neurology 82:1245-1253.

Chandra D, Halonen LM, Linden AM, Procaccini C, Hellsten K, Homanics GE, and Korpi ER (2010) Prototypic GABA(A) receptor agonist muscimol acts preferentially through forebrain high-affinity binding sites. Neuropsychopharmacology 35:999-1007.

Chandra D, Jia F, Liang J, Peng Z, Suryanarayanan A, Werner DF, Spigelman I, Houser CR, Olsen RW, Harrison NL, et al. (2006) GABAA receptor alpha 4 subunits mediate extrasynaptic inhibition in thalamus and dentate gyrus and the action of gaboxadol. Proc Natl Acad Sci USA 103:15230-15235.

Chandra D, Korpi ER, Miralles CP, De Blas AL, and Homanics GE (2005) GABAA receptor gamma 2 subunit knockdown mice have enhanced anxiety-like behavior but unaltered hypnotic response to benzodiazepines. BMC Neurosci 6:30.

Chaumont S, André C, Perrais D, Boué-Grabot E, Taly A, and Garret M (2013) Agonist-dependent endocytosis of $\gamma$-aminobutyric acid type A (GABAA) receptors revealed by a $\gamma 2(\mathrm{R} 43 \mathrm{Q})$ epilepsy mutation. J Biol Chem 288: $28254-28265$.

Collinson N, Kuenzi FM, Jarolimek W, Maubach KA, Cothliff R, Sur C, Smith A, Otu FM, Howell O, Atack JR, et al. (2002) Enhanced learning and memory and altered GABAergic synaptic transmission in mice lacking the alpha 5 subunit of the GABAA receptor. $J$ Neurosci 22:5572-5580.

Cossette P, Liu L, Brisebois K, Dong H, Lortie A, Vanasse M, Saint-Hilaire JM, Carmant L, Verner A, Lu WY, et al. (2002) Mutation of GABRA1 in an autosomal dominant form of juvenile myoclonic epilepsy. Nat Genet 31:184-189.

Coulter DA (2000) Mossy fiber zinc and temporal lobe epilepsy: pathological association with altered "epileptic" gamma-aminobutyric acid A receptors in dentate granule cells. Epilepsia 41 (Suppl 6):S96-S99

Coulter DA and Carlson GC (2007) Functional regulation of the dentate gyrus by GABA-mediated inhibition. Prog Brain Res 163:235-243.

Clossen BL and Reddy DS (2017) Catamenial-like seizure exacerbation in mice with targeted ablation of extrasynaptic $\delta$ GABA-a receptors in the brain. $J$ Neurosci Res 95:1906-1916.

Crestani F, Keist R, Fritschy JM, Benke D, Vogt K, Prut L, Blüthmann H, Möhler H, and Rudolph U (2002) Trace fear conditioning involves hippocampal alpha5 GABA (A) receptors. Proc Natl Acad Sci USA 99:8980-8985.

Dibbens LM, Feng HJ, Richards MC, Harkin LA, Hodgson BL, Scott D, Jenkins M, Petrou S, Sutherland GR, Scheffer IE, et al. (2004) GABRD encoding a protein for extra- or peri-synaptic GABAA receptors is a susceptibility locus for generalized epilepsies. Hum Mol Genet 13:1315-1319.

Dibbens LM, Harkin LA, Richards M, Hodgson BL, Clarke AL, Petrou S, Scheffer IE, Berkovic SF, and Mulley JC (2009) The role of neuronal GABA(A) receptor subunit mutations in idiopathic generalized epilepsies. Neurosci Lett 453:162-165.

Ding L, Feng HJ, Macdonald RL, Botzolakis EJ, Hu N, and Gallagher MJ (2010) GABA(A) receptor alpha1 subunit mutation A322D associated with autosomal 
dominant juvenile myoclonic epilepsy reduces the expression and alters the composition of wild type GABA(A) receptors. $J$ Biol Chem 285:26390-26405.

Drasbek KR and Jensen K (2006) THIP, a hypnotic and antinociceptive drug, enhances an extrasynaptic GABAA receptor-mediated conductance in mouse neocortex. Cereb Cortex 16:1134-1141.

Eslami M, Ghanbari E, Sayyah M, Etemadi F, Choopani S, Soleimani M, Amiri Z, and Hadjighassem M (2016) Traumatic brain injury accelerates kindling epileptogenesis in rats. Neurol Res 38:269-274.

Esmaeili A, Lynch JW, and Sah P (2009) GABAA receptors containing gamma1 subunits contribute to inhibitory transmission in the central amygdala. J Neurophysiol 101:341-349.

Essrich C, Lorez M, Benson JA, Fritschy JM, and Lüscher B (1998) Postsynaptic clustering of major GABAA receptor subtypes requires the gamma 2 subunit and gephyrin. Nat Neurosci 1:563-571.

Fáncsik A, Linn DM, and Tasker JG (2000) Neurosteroid modulation of GABA IPSCs is phosphorylation dependent. $J$ Neurosci 20:3067-3075.

Fang C, Deng L, Keller CA, Fukata M, Fukata Y, Chen G, and Lüscher B (2006) GODZ-mediated palmitoylation of GABA(A) receptors is required for norma assembly and function of GABAergic inhibitory synapses. $J$ Neurosci 26 12758-12768.

Farrant M and Nusser Z (2005) Variations on an inhibitory theme: phasic and tonic activation of GABA(A) receptors. Nat Rev Neurosci 6:215-229.

Feng HJ, Kang JQ, Song L, Dibbens L, Mulley J, and Macdonald RL (2006) Delta subunit susceptibility variants E177A and R220H associated with complex epilepsy alter channel gating and surface expression of alpha4beta2delta GABAA receptors. J Neurosci 26:1499-1506.

Feucht M, Fuchs K, Pichlbauer E, Hornik K, Scharfetter J, Goessler R, Füreder T, Cvetkovic N, Sieghart W, Kasper S, et al. (1999) Possible association between childhood absence epilepsy and the gene encoding GABRB3. Biol Psychiatry 46:997-1002.

Foresti ML, Arisi GM, Fernandes A, Tilelli CQ, and Garcia-Cairasco N (2008) Chelatable zinc modulates excitability and seizure duration in the amygdala rapid kindling model. Epilepsy Res 79:166-172.

Frederickson CJ (1989) Neurobiology of zinc and zinc-containing neurons. Int Rev Neurobiol 31:145-238.

Fritschy JM and Mohler H (1995) GABAA-receptor heterogeneity in the adult rat brain: differential regional and cellular distribution of seven major subunits. $J$ Comp Neurol 359:154-194.

Frugier G, Coussen F, Giraud MF, Odessa MF, Emerit MB, Boué-Grabot E and Garret M (2007) A gamma 2(R43Q) mutation, linked to epilepsy in humans, alters GABAA receptor assembly and modifies subunit composition on the cell surface. J Biol Chem 282:3819-3828

Galimberti CA, Magri F, Copello F, Arbasino C, Cravello L, Casu M, Patrone V, and Murialdo G (2005) Seizure frequency and cortisol and dehydroepiandrosterone sulfate (DHEAS) levels in women with epilepsy receiving antiepileptic drug treatment. Epilepsia 46:517-523.

Gallagher MJ, Ding L, Maheshwari A, and Macdonald RL (2007) The GABAA receptor alpha1 subunit epilepsy mutation A322D inhibits transmembrane helix formation and causes proteasomal degradation. Proc Natl Acad Sci USA 104: 12999-13004.

Gallagher MJ, Song L, Arain F, and Macdonald RL (2004) The juvenile myoclonic epilepsy GABA(A) receptor alpha1 subunit mutation A322D produces asymmetrical, subunit position-dependent reduction of heterozygous receptor currents and alpha1 subunit protein expression. J Neurosci 24:5570-5578.

Gangisetty O and Reddy DS (2010) Neurosteroid withdrawal regulates GABA-A receptor $\alpha 4$-subunit expression and seizure susceptibility by activation of progesterone receptor-independent early growth response factor-3 pathway. Neuroscience 170:865-880.

Glykys J, Mann EO, and Mody I (2008) Which GABA(A) receptor subunits are necessary for tonic inhibition in the hippocampus? J Neurosci 28:1421-1426.

Glykys J and Mody I (2007) Activation of GABAA receptors: views from outside the synaptic cleft. Neuron 56:763-770.

Glykys J, Peng Z, Chandra D, Homanics GE, Houser CR, and Mody I (2007) A new naturally occurring GABA(A) receptor subunit partnership with high sensitivity to ethanol. Nat Neurosci 10:40-48.

Gurba KN, Hernandez CC, Hu N, and Macdonald RL (2012) GABRB3 mutation, G32R, associated with childhood absence epilepsy alters $\alpha 1 \beta 3 \gamma 2 \mathrm{~L} \gamma$-aminobutyric acid type A (GABAA) receptor expression and channel gating. J Biol Chem 287:12083-12097.

Hancili S, Önal ZE, Ata P, Karatoprak EY, Gürbüz T, Bostancı M, Paçal Y, Nuhoğlu C, and Ceran Ö (2014) The GABAA receptor $\gamma 2$ subunit (R43Q) mutation in febrile seizures. Pediatr Neurol 50:353-356.

Harkin LA, Bowser DN, Dibbens LM, Singh R, Phillips F, Wallace RH, Richards MC, Williams DA, Mulley JC, Berkovic SF, et al. (2002) Truncation of the GABA(A)receptor gamma2 subunit in a family with generalized epilepsy with febrile seizures plus. Am J Hum Genet 70:530-536.

Harney SC, Frenguelli BG, and Lambert JJ (2003) Phosphorylation influences neurosteroid modulation of synaptic GABAA receptors in rat CA1 and dentate gyrus neurones. Neuropharmacology 45:873-883.

Harrison NL and Gibbons SJ (1994) Zn2+: an endogenous modulator of ligand- and voltage-gated ion channels. Neuropharmacology 33:935-952.

Hauser WA (1994) The prevalence and incidence of convulsive disorders in children. Epilepsia 35 (Suppl 2):S1-S6.

Hempelmann A, Cobilanschi J, Heils A, Muhle H, Stephani U, Weber Y, Lerche H and Sander T (2007) Lack of evidence of an allelic association of a functional GABRB3 exon 1a promoter polymorphism with idiopathic generalized epilepsy. Epilepsy Res 74:28-32.

Herd MB, Haythornthwaite AR, Rosahl TW, Wafford KA, Homanics GE, Lambert JJ, and Belelli D (2008) The expression of GABAA beta subunit isoforms in synaptic and extrasynaptic receptor populations of mouse dentate gyrus granule cells. $J$ Physiol 586:989-1004.
Hernandez CC, Gurba KN, Hu N, and Macdonald RL (2011) The GABRA6 mutation, R46W, associated with childhood absence epilepsy, alters alpha6beta2gamma2 and alpha6beta2delta GABA-A receptor channel gating and expression. J Physiol 589 $5857-5878$.

Herzog AG, Fowler KM, Smithson SD, Kalayjian LA, Heck CN, Sperling MR, Liporace JD, Harden CL, Dworetzky BA, Pennell PB, et al.; Progesterone Trial Study Group (2012) Progesterone vs placebo therapy for women with epilepsy: a randomized clinical trial. Neurology 78:1959-1966.

Hesdorffer DC, Beck V, Begley CE, Bishop ML, Cushner-Weinstein S, Holmes GL, Shafer PO, Sirven JI, and Austin JK (2013) Research implications of the Institute of Medicine report, epilepsy across the spectrum: promoting health and understanding. Epilepsia 54:207-216.

Hirose S (2006) A new paradigm of channelopathy in epilepsy syndromes: in tracellular trafficking abnormality of channel molecules. Epilepsy Res $\mathbf{7 0}$ (Suppl 1): S206-S217.

Homanics GE, DeLorey TM, Firestone LL, Quinlan JJ, Handforth A, Harrison NL Krasowski MD, Rick CE, Korpi ER, Mäkelä R, et al. (1997) Mice devoid of gammaaminobutyrate type A receptor beta3 subunit have epilepsy, cleft palate, and hypersensitive behavior. Proc Natl Acad Sci USA 94:4143-4148.

Hosie AM, Dunne EL, Harvey RJ, and Smart TG (2003) Zinc-mediated inhibition of GABA(A) receptors: discrete binding sites underlie subtype specificity. Nat $\mathrm{Neu}$ rosci 6:362-369.

Hosie AM, Wilkins ME, and Smart TG (2007) Neurosteroid binding sites on GABA(A) receptors. Pharmacol Ther 116:7-19.

Huang X, Hernandez CC, Hu N, and Macdonald RL (2014) Three epilepsy-associated GABRG2 missense mutations at the $\gamma+/ \beta$ - interface disrupt GABAA receptor assembly and trafficking by similar mechanisms but to different extents. Neurobiol Dis 68:167-179.

Ishii A, Kanaumi T, Sohda M, Misumi Y, Zhang B, Kakinuma N, Haga Y, Watanabe K, Takeda S, Okada M, et al. (2014) Association of nonsense mutation in GABRG2 with abnormal trafficking of GABAA receptors in severe epilepsy. Epilepsy Res 108:420-432.

Jia F, Pignataro L, and Harrison NL (2007) GABAA receptors in the thalamus: alpha4 subunit expression and alcohol sensitivity. Alcohol 41:177-185.

Jia F, Pignataro L, Schofield CM, Yue M, Harrison NL, and Goldstein PA (2005) An extrasynaptic GABAA receptor mediates tonic inhibition in thalamic VB neurons. $J$ Neurophysiol 94:4491-4501.

Johannesen K, Marini C, Pfeffer S, Møller RS, Dorn T, Niturad CE, Gardella E, Weber Y, Søndergård M, Hjalgrim H, et al. (2016) Phenotypic spectrum of GABRA1: from generalized epilepsies to severe epileptic encephalopathies. $\mathrm{Neu}$ rology 87:1140-1151.

Johnston AJ, Kang JQ, Shen W, Pickrell WO, Cushion TD, Davies JS, Baer K, Mullins JGL, Hammond CL, Chung SK, et al. (2014) A novel GABRG2 mutation, p. R136*, in a family with GEFS+ and extended phenotypes. Neurobiol Dis 64: 131-141.

Jones A, Korpi ER, McKernan RM, Pelz R, Nusser Z, Mäkelä R, Mellor JR, Pollard S, Bahn S, Stephenson FA, et al. (1997) Ligand-gated ion channel subunit partnerships: GABAA receptor alpha6 subunit gene inactivation inhibits delta subunit expression. J Neurosci 17:1350-1362.

Joshi S, Rajasekaran K, Williamson J, and Kapur J (2017) Neurosteroid-sensitive $\delta$-GABAA receptors: a role in epileptogenesis? Epilepsia 58:494-504.

Jurd R, Arras M, Lambert S, Drexler B, Siegwart R, Crestani F, Zaugg M, Vogt KE, Ledermann B, Antkowiak B, et al. (2003) General anesthetic actions in vivo strongly attenuated by a point mutation in the $\mathrm{GABA}(\mathrm{A})$ receptor beta3 subunit. FASEB J 17:250-252.

Kanes S, Colquhoun H, Gunduz-Bruce H, Raines S, Arnold R, Schacterle A, Doherty J, Epperson CN, Deligiannidis KM, Riesenberg R, et al. (2017) Brexanolone (SAGE-547 injection) in post-partum depression: a randomised controlled trial. Lancet 390:480-489.

Kananura C, Haug K, Sander T, Runge U, Gu W, Hallmann K, Rebstock J, Heils A, and Steinlein OK (2002) A splice-site mutation in GABRG2 associated with childhood absence epilepsy and febrile convulsions. Arch Neurol 59:1137-1141.

Kang JQ and Macdonald RL (2004) The GABAA receptor gamma2 subunit R43Q mutation linked to childhood absence epilepsy and febrile seizures causes retention of alpha1beta2gamma2S receptors in the endoplasmic reticulum. $J$ Neurosci 24 : 8672-8677.

Kang JQ, Shen W, Lee M, Gallagher MJ, and Macdonald RL (2010) Slow degradation and aggregation in vitro of mutant GABAA receptor gamma2(Q351X) subunits associated with epilepsy. J Neurosci 30:13895-13905.

Kang JQ, Shen W, Zhou C, Xu D, and Macdonald RL (2015) The human epilepsy mutation GABRG2(Q390X) causes chronic subunit accumulation and neurodegeneration. Nat Neurosci 18:988-996.

Kerrigan JF, Shields WD, Nelson TY, Bluestone DL, Dodson WE, Bourgeois BF, Pellock JM, Morton LD, and Monaghan EP (2000) Ganaxolone for treating intractable infantile spasms: a multicenter, open-label, add-on trial. Epilepsy Res 42:133-139.

Kittler JT, Chen G, Honing S, Bogdanov Y, McAinsh K, Arancibia-Carcamo IL, Jovanovic JN, Pangalos MN, Haucke V, Yan Z, et al. (2005) Phospho-dependent binding of the clathrin AP2 adaptor complex to GABAA receptors regulates the efficacy of inhibitory synaptic transmission. Proc Natl Acad Sci USA 102: 14871-14876.

Kittler JT, Chen G, Kukhtina V, Vahedi-Faridi A, Gu Z, Tretter V, Smith KR, McAinsh K, Arancibia-Carcamo IL, Saenger W, et al. (2008) Regulation of synaptic inhibition by phospho-dependent binding of the AP2 complex to a YECL motif in the GABAA receptor gamma2 subunit. Proc Natl Acad Sci USA 105:3616-3621.

Kodera H, Ohba C, Kato M, Maeda T, Araki K, Tajima D, Matsuo M, Hino-Fukuyo N, Kohashi K, Ishiyama A, et al. (2016) De novo GABRA1 mutations in Ohtahara and West syndromes. Epilepsia 57:566-573.

Korpi ER, Mihalek RM, Sinkkonen ST, Hauer B, Hevers W, Homanics GE, Sieghart W, and Lüddens H (2002) Altered receptor subtypes in the forebrain of GABA(A) 
receptor delta subunit-deficient mice: recruitment of gamma 2 subunits. Neuroscience 109:733-743.

Kralic JE, Wheeler M, Renzi K, Ferguson C, O’Buckley TK, Grobin AC, Morrow AL and Homanics GE (2003) Deletion of GABAA receptor alpha 1 subunit-containing receptors alters responses to ethanol and other anesthetics. J Pharmacol Exp Ther 305:600-607.

Krampfl K, Maljevic S, Cossette P, Ziegler E, Rouleau GA, Lerche H, and Bufler J (2005) Molecular analysis of the A322D mutation in the GABA receptor alphasubunit causing juvenile myoclonic epilepsy. Eur $J$ Neurosci 22:10-20

Krishek BJ, Xie X, Blackstone C, Huganir RL, Moss SJ, and Smart TG (1994) Regulation of GABAA receptor function by protein kinase C phosphorylation. Neuron 12:1081-1095.

Kulkarni SK and Reddy DS (1995) Neurosteroids: a new class of neuromodulators. Drugs Today (Barc) 31:433-455.

Lachance-Touchette P, Brown P, Meloche C, Kinirons P, Lapointe L, Lacasse H, Lortie A, Carmant L, Bedford F, Bowie D, et al. (2011) Novel $\alpha 1$ and $\gamma 2$ GABAA receptor subunit mutations in families with idiopathic generalized epilepsy. Eur $J$ Neurosci 34:237-249.

Lachance-Touchette P, Martin C, Poulin C, Gravel M, Carmant L, and Cossette P (2010) Screening of GABRB3 in French-Canadian families with idiopathic generalized epilepsy. Epilepsia 51:1894-1897.

Laxer K, Blum D, Abou-Khalil BW, Morrell MJ, Lee DA, Data JL, and Monaghan EP; Ganaxolone Presurgical Study Group (2000) Assessment of ganaxolone's anticonvulsant activity using a randomized, double-blind, presurgical trial design. Epilepsia 41:1187-1194.

Leidenheimer NJ and Chapell R (1997) Effects of PKC activation and receptor desensitization on neurosteroid modulation of GABA(A) receptors. Brain Res Mol Brain Res 52:173-181.

Ligsay A, Van Dijck A, Nguyen DV, Lozano R, Chen Y, Bickel ES, Hessl D, Schneider A, Angkustsiri K, Tassone F, et al. (2017) A randomized double-blind, placebocontrolled trial of ganaxolone in children and adolescents with fragile X syndrome. J Neurodev Disord 9:26.

Loup F, Wieser HG, Yonekawa Y, Aguzzi A, and Fritschy JM (2000) Selective alterations in GABAA receptor subtypes in human temporal lobe epilepsy. $J \mathrm{Neu}$ rosci 20:5401-5419.

Löw K, Crestani F, Keist R, Benke D, Brünig I, Benson JA, Fritschy JM, Rülicke T, Bluethmann H, Möhler H, et al. (2000) Molecular and neuronal substrate for the selective attenuation of anxiety. Science 290:131-134.

Majewska MD, Demirgören S, Spivak CE, and London ED (1990) The neurosteroid dehydroepiandrosterone sulfate is an allosteric antagonist of the GABAA receptor. Brain Res 526:143-146.

Maljevic S, Krampfl K, Cobilanschi J, Tilgen N, Beyer S, Weber YG, Schlesinger F, Ursu D, Melzer W, Cossette P, et al. (2006) A mutation in the GABA(A) receptor alpha(1)-subunit is associated with absence epilepsy. Ann Neurol 59:983-987.

Marowsky A, Fritschy JM, and Vogt KE (2004) Functional mapping of GABA A receptor subtypes in the amygdala. Eur J Neurosci 20:1281-1289.

Marowsky A, Rudolph U, Fritschy JM, and Arand M (2012) Tonic inhibition in principal cells of the amygdala: a central role for $\alpha 3$ subunit-containing GABAA receptors. J Neurosci 32:8611-8619.

McDonald BJ, Amato A, Connolly CN, Benke D, Moss SJ, and Smart TG (1998) Adjacent phosphorylation sites on GABAA receptor beta subunits determine regulation by cAMP-dependent protein kinase Nat Neurosci 1:23-28.

McKernan RM, Rosahl TW, Reynolds DS, Sur C, Wafford KA, Atack JR, Farrar S, Myers J, Cook G, Ferris P, et al. (2000) Sedative but not anxiolytic properties of benzodiazepines are mediated by the GABA(A) receptor alpha1 subtype. Nat Neurosci 3:587-592.

McKernan RM and Whiting PJ (1996) Which GABAA-receptor subtypes really occur in the brain? Trends Neurosci 19:139-143.

Meera P, Wallner M, and Otis TS (2011) Molecular basis for the high THIP/gaboxadol sensitivity of extrasynaptic GABA(A) receptors. $J$ Neurophysiol 106:2057-2064.

Meletti S, Lucchi C, Monti G, Giovannini G, Bedin R, Trenti T, Rustichelli C, and Biagini G (2017) Decreased allopregnanolone levels in cerebrospinal fluid obtained during status epilepticus. Epilepsia 58:e16-e20.

Mellon SH and Griffin LD (2002) Synthesis, regulation, and function of neurosteroids. Endocr Res 28:463.

Mihalek RM, Banerjee PK, Korpi ER, Quinlan JJ, Firestone LL, Mi ZP, Lagenaur C, Tretter V, Sieghart W, Anagnostaras SG, et al. (1999) Attenuated sensitivity to neuroactive steroids in gamma-aminobutyrate type A receptor delta subunit knockout mice. Proc Natl Acad Sci USA 96:12905-12910.

Modgil A, Parakala ML, Ackley MA, Doherty JJ, Moss SJ, and Davies PA (2017) Endogenous and synthetic neuroactive steroids evoke sustained increases in the efficacy of GABAergic inhibition via a protein kinase C-dependent mechanism. Neuropharmacology 113 (Pt A):314-322.

Möhler H, Fritschy JM, and Rudolph U (2002) A new benzodiazepine pharmacology. $J$ Pharmacol Exp Ther $\mathbf{3 0 0} \cdot 2$

Mortensen M, Patel B, and Smart TG (2012) GABA potency at GABA(A) receptors found in synaptic and extrasynaptic zones. Front Cell Neurosci 6:1-12.

Moss SJ, Gorrie GH, Amato A, and Smart TG (1995) Modulation of GABAA receptors by tyrosine phosphorylation. Nature 377:344-348.

Moss SJ and Smart TG (1996) Modulation of amino acid-gated ion channels by protein phosphorylation. Int Rev Neurobiol 39:1-52.

Naylor DE, Liu H, and Wasterlain CG (2005) Trafficking of GABA(A) receptors, loss of inhibition, and a mechanism for pharmacoresistance in status epilepticus. J Neurosci 25:7724-7733.

Nohria V and Giller E (2007) Ganaxolone. Neurotherapeutics 4:102-105.

Nusser Z, Sieghart W, and Somogyi P (1998) Segregation of different GABAA receptors to synaptic and extrasynaptic membranes of cerebellar granule cells. $J$ Neurosci 18:1693-1703.

Nutt D (2006) GABAA receptors: subtypes, regional distribution, and function. J Clin Sleep Med 2:S7-S11.
Olmos-Serrano JL, Paluszkiewicz SM, Martin BS, Kaufmann WE, Corbin JG, and Huntsman MM (2010) Defective GABAergic neurotransmission and pharmacological rescue of neuronal hyperexcitability in the amygdala in a mouse model of fragile X syndrome. J Neurosci 30:9929-9938.

Olsen RW and Sieghart W (2009) GABA A receptors: subtypes provide diversity of function and pharmacology. Neuropharmacology 56:141-148.

Pack AM, Reddy DS, Duncan S, and Herzog A (2011) Neuroendocrinological aspects of epilepsy: important issues and trends in future research. Epilepsy Behav 22: 94-102.

Paul SM and Purdy RH (1992) Neuroactive steroids. FASEB $J$ 6:2311-2322.

Peng Z, Hauer B, Mihalek RM, Homanics GE, Sieghart W, Olsen RW, and Houser CR (2002) GABA(A) receptor changes in delta subunit-deficient mice: altered expression of alpha4 and gamma2 subunits in the forebrain. J Comp Neurol 446:179-197.

Pieribone VA, Tsai J, Soufflet C, Rey E, Shaw K, Giller E, and Dulac O (2007) Clinical evaluation of ganaxolone in pediatric and adolescent patients with refractory epilepsy. Epilepsia 48:1870-1874.

Pirker S, Schwarzer C, Wieselthaler A, Sieghart W, and Sperk G (2000) GABA(A) receptors: immunocytochemical distribution of 13 subunits in the adult rat brain. Neuroscience 101:815-850.

Pitkänen A, Roivainen R, and Lukasiuk K (2016) Development of epilepsy after ischaemic stroke. Lancet Neurol 15:185-197.

Porcello DM, Huntsman MM, Mihalek RM, Homanics GE, and Huguenard JR (2003) Intact synaptic GABAergic inhibition and altered neurosteroid modulation of thalamic relay neurons in mice lacking delta subunit. $J$ Neurophysiol 89: 1378-1386.

Porcu P, Barron AM, Frye CA, Walf AA, Yang SY, He XY, Morrow AL, Panzica GC, and Melcangi RC (2016) Neurosteroidogenesis today: novel targets for neuroactive steroid synthesis and action and their relevance for translational research. $J$ Neuroendocrinol 28:12351.

Reddy DS (2003a) Is there a physiological role for the neurosteroid THDOC in stresssensitive conditions? Trends Pharmacol Sci 24:103-106.

Reddy DS (2003b) Pharmacology of endogenous neuroactive steroids. Crit Rev Neurobiol 15:197-234.

Reddy DS (2006) Physiological role of adrenal deoxycorticosterone-derived neuroactive steroids in stress-sensitive conditions. Neuroscience 138:911-920.

Reddy DS (2009a) The role of neurosteroids in the pathophysiology and treatment of catamenial epilepsy. Epilepsy Res 85:1-30.

Reddy DS (2009b) Gender differences in antiseizure sensitivity of neurosteroids in the pilocarpine model of status epilepticus. Epilepsia 50 (Suppl 11):126.

Reddy DS (2011) Role of anticonvulsant and antiepileptogenic neurosteroids in the pathophysiology and treatment of epilepsy. Front Endocrinol (Lausanne) 2:38

Reddy DS (2013a) Neuroendocrine aspects of catamenial epilepsy. Horm Behav 63 $254-266$.

Reddy DS (2013b) Role of hormones and neurosteroids in epileptogenesis. Front Cell Neurosci 7:115.

Reddy DS (2014) Neurosteroids and their role in sex-specific epilepsies. Neurobiol Dis 72 (Pt B):198-209.

Reddy DS (2016a) Catamenial epilepsy: discovery of an extrasynaptic molecular mechanism for targeted therapy. Front Cell Neurosci 10:101.

Reddy DS (2016b) Neurosteroids for the potential protection of humans against organophosphate toxicity. Ann N Y Acad Sci 1378:25-32.

Reddy DS (2017) The neuroendocrine basis of sex differences in epilepsy. Pharmacol Biochem Behav 152:97-104.

Reddy DS and Estes WA (2016) Clinical potential of neurosteroids for CNS disorders. Trends Pharmacol Sci 37:543-561.

Reddy DS, Gould J, and Gangisetty O (2012) A mouse kindling model of perimenstrual catamenial epilepsy. $J$ Pharmacol Exp Ther 341:784-793.

Reddy DS and Jian K (2010) The testosterone-derived neurosteroid androstanediol is a positive allosteric modulator of GABAA receptors. J Pharmacol Exp Ther 334: 1031-1041.

Reddy DS, Kim HY, and Rogawski MA (2001) Neurosteroid withdrawal model of perimenstrual catamenial epilepsy. Epilepsia 42:328-336.

Reddy DS and Kulkarni SK (1998) Proconvulsant effects of neurosteroids pregnenolone sulfate and dehydroepiandrosterone sulfate in mice. Eur $J$ Pharmacol 345 $55-59$.

Reddy DS and Rogawski MA (2000a) Chronic treatment with the neuroactive steroid ganaxolone in the rat induces anticonvulsant tolerance to diazepam but not to itself. $J$ Pharmacol Exp Ther 295:1241-1248.

Reddy DS and Rogawski MA (2000b) Enhanced anticonvulsant activity of ganaxolone after neurosteroid withdrawal in a rat model of catamenial epilepsy. $J$ Pharmaco Exp Ther 294:909-915.

Reddy DS and Rogawski MA (2001) Enhanced anticonvulsant activity of neuroactive steroids in a rat model of catamenial epilepsy. Epilepsia 42:337-344.

Reddy DS and Rogawski MA (2002) Stress-induced deoxycorticosterone-derived neurosteroids modulate $\operatorname{GABA}(\mathrm{A})$ receptor function and seizure susceptibility. $J$ Neurosci 22:3795-3805.

Reddy DS and Rogawski MA (2009) Neurosteroid replacement therapy for catamenial epilepsy. Neurotherapeutics 6:392-401.

Reddy DS and Rogawski MA (2010) Ganaxolone suppression of behavioral and electrographic seizures in the mouse amygdala kindling model. Epilepsy Res 89: $254-260$.

Reddy DS and Rogawski MA (2012) Neurosteroids-endogenous regulators of seizure susceptibility and role in the treatment of epilepsy, in Jasper's Basic Mechanisms of the Epilepsies (Noebels JL, Avoli M, Rogawski MA, Olsen RW, and DelgadoEscueta AV eds) pp 984-1002, Oxford University Press, New York.

Reddy DS and Woodward R (2004) Ganaxolone: a prospective overview. Drugs Future 29:227-242.

Reddy SD and Reddy DS (2015) Midazolam as an anticonvulsant antidote for organophosphate intoxication-a pharmacotherapeutic appraisal. Epilepsia 56: 813-821. 
Reddy SD, Younus I, Clossen BL, and Reddy DS (2015) Antiseizure activity of midazolam in mice lacking delta subunit extrasynaptic GABA-A receptors. $J$ Pharmacol Exp Ther 353:517-528.

Rogawski MA, Loya CM, Reddy K, Zolkowska D, and Lossin C (2013) Neuroactive steroids for the treatment of status epilepticus. Epilepsia 54 (Suppl 6) 93-98.

Rosenthal ES, Claassen J, Wainwright MS, Husain AM, Vaitkevicius H, Raines S, Hoffmann E, Colquhoun H, Doherty JJ, and Kanes SJ (2017) Brexanolone as adjunctive therapy in super-refractory status epilepticus. Ann Neurol 82 342-352.

Rudolph U, Crestani F, Benke D, Brünig I, Benson JA, Fritschy JM, Martin JR, Bluethmann H, and Möhler H (1999) Benzodiazepine actions mediated by specific gamma-aminobutyric acid(A) receptor subtypes. Nature 401:796-800.

Ruiz A, Walker MC, Fabian-Fine R, and Kullmann DM (2004) Endogenous zinc inhibits GABA(A) receptors in a hippocampal pathway. $J$ Neurophysiol 91: 1091-1096.

Rupprecht R (2003) Neuroactive steroids: mechanisms of action and neuropsychopharmacological properties. Psychoneuroendocrinology 28:139-168.

Rupprecht R, Reul JM, Trapp T, van Steensel B, Wetzel C, Damm K, Zieglgänsberger W, and Holsboer F (1993) Progesterone receptor-mediated effects of neuroactive steroids. Neuron 11:523-530.

Russek SJ (1999) Evolution of GABA(A) receptor diversity in the human genome. Gene 227:213-222.

Saliba RS, Kretschmannova K, and Moss SJ (2012) Activity-dependent phosphorylation of GABAA receptors regulates receptor insertion and tonic current. EMBO J 31:2937-2951.

Shen H, Sabaliauskas N, Sherpa A, Fenton AA, Stelzer A, Aoki C, and Smith SS (2010) A critical role for alpha4betadelta GABAA receptors in shaping learning deficits at puberty in mice. Science 327:1515-1518.

Sieghart W (1995) Structure and pharmacology of gamma-aminobutyric acidA receptor subtypes. Pharmacol Rev 47:181-234.

Sieghart W and Sperk G (2002) Subunit composition, distribution and function of GABA(A) receptor subtypes. Curr Top Med Chem 2:795-816.

Smart TG, Moss SJ, Xie X, and Huganir RL (1991) GABAA receptors are differentially sensitive to zinc: dependence on subunit composition. $\mathrm{Br} J$ Pharmacol 103 1837-1839

Sperk G, Schwarzer C, Tsunashima K, Fuchs K, and Sieghart W (1997) GABA(A) receptor subunits in the rat hippocampus I: immunocytochemical distribution of 13 subunits. Neuroscience 80:987-1000.

Sperling MR, Klein P, and Tsai J (2017) Randomized, double-blind, placebocontrolled phase 2 study of ganaxolone as add-on therapy in adults with uncontrolled partial-onset seizures. Epilepsia 58:558-564.

Spigelman I, Li Z, Banerjee PK, Mihalek RM, Homanics GE, and Olsen RW (2002) Behavior and physiology of mice lacking the GABAA-receptor delta subunit. Epilepsia 43 (Suppl 5):3-8.

Spigelman I, Li Z, Liang J, Cagetti E, Samzadeh S, Mihalek RM, Homanics GE, and Olsen RW (2003) Reduced inhibition and sensitivity to neurosteroids in hippocampus of mice lacking the GABA(A) receptor delta subunit. $J$ Neurophysiol $\mathbf{9 0}$ 903-910.

Srivastava S, Cohen J, Pevsner J, Aradhya S, McKnight D, Butler E, Johnston M, and Fatemi A (2014) A novel variant in GABRB2 associated with intellectual disability and epilepsy. Am J Med Genet A 164A:2914-2921.

Stell BM, Brickley SG, Tang CY, Farrant M, and Mody I (2003) Neuroactive steroids reduce neuronal excitability by selectively enhancing tonic inhibition mediated by delta subunit-containing GABAA receptors. Proc Natl Acad Sci USA 100 14439-14444.

Stórustovu SI and Ebert B (2006) Pharmacological characterization of agonists at delta-containing GABAA receptors: functional selectivity for extrasynaptic receptors is dependent on the absence of gamma2. J Pharmacol Exp Ther 316 1351-1359.

Sun C, Sieghart W, and Kapur J (2004) Distribution of alpha1, alpha4, gamma2, and delta subunits of GABAA receptors in hippocampal granule cells. Brain Res 1029 $207-216$

Sun H, Zhang Y, Liang J, Liu X, Ma X, Wu H, Xu K, Qin J, Qi Y, and Wu X (2008) SCN1A, SCN1B, and GABRG2 gene mutation analysis in Chinese families with generalized epilepsy with febrile seizures plus. J Hum Genet 53:769-774.

Takeda A, Hanajima T, Ijiro H, Ishige A, Iizuka S, Okada S, and Oku N (1999) Release of zinc from the brain of El (epilepsy) mice during seizure induction. Brain Res 828:174-178.
Tan HO, Reid CA, Single FN, Davies PJ, Chiu C, Murphy S, Clarke AL, Dibbens L, Krestel H, Mulley JC, et al. (2007) Reduced cortical inhibition in a mouse model of familial childhood absence epilepsy. Proc Natl Acad Sci USA 104:17536-17541.

Tanaka M, Olsen RW, Medina MT, Schwartz E, Alonso ME, Duron RM, CastroOrtega R, Martinez-Juarez IE, Pascual-Castroviejo I, Machado-Salas J, et al. (2008) Hyperglycosylation and reduced GABA currents of mutated GABRB3 polypeptide in remitting childhood absence epilepsy. Am J Hum Genet 82 : 1249-1261.

Thurman DJ, Beghi E, Begley CE, Berg AT, Buchhalter JR, Ding D, Hesdorffer DC, Hauser WA, Kazis L, Kobau R, et al.; ILAE Commission on Epidemiology (2011) Standards for epidemiologic studies and surveillance of epilepsy. Epilepsia $\mathbf{5 2}$ (Suppl 7):2-26.

Tian M, Mei D, Freri E, Hernandez CC, Granata T, Shen W, Macdonald RL, and Guerrini $R$ (2013) Impaired surface $\alpha \beta \gamma \operatorname{GABA}(\mathrm{A})$ receptor expression in familial epilepsy due to a GABRG2 frameshift mutation. Neurobiol Dis 50:135-141.

Tian Y, Yang Z, and Zhang T (2010) Zinc ion as modulator effects on excitability and synaptic transmission in hippocampal CA1 neurons in Wistar rats. Neurosci Res 68:167-175.

Todd E, Gurba KN, Botzolakis EJ, Stanic AK, and Macdonald RL (2014) GABAA receptor biogenesis is impaired by the $\gamma 2$ subunit febrile seizure-associated mutation, GABRG2(R177G). Neurobiol Dis 69:215-224

Urak L, Feucht M, Fathi N, Hornik K, and Fuchs K (2006) A GABRB3 promoter haplotype associated with childhood absence epilepsy impairs transcriptional activity. Hum Mol Genet 15:2533-2541.

Vaitkevicius H, Husain AM, Rosenthal ES, Rosand J, Bobb W, Reddy K, Rogawski MA, and Cole AJ (2017) First-in-man allopregnanolone use in super-refractory status epilepticus. Ann Clin Transl Neurol 4:411-414.

Vezzani A, Fujinami RS, White HS, Preux PM, Blümcke I, Sander JW, and Löscher W (2016) Infections, inflammation and epilepsy. Acta Neuropathol 131:211-234.

Vicini S, Losi G, and Homanics GE (2002) GABA(A) receptor delta subunit deletion prevents neurosteroid modulation of inhibitory synaptic currents in cerebellar neurons. Neuropharmacology 43:646-650.

Wallace RH, Marini C, Petrou S, Harkin LA, Bowser DN, Panchal RG, Williams DA Sutherland GR, Mulley JC, Scheffer IE, et al. (2001) Mutant GABA(A) receptor gamma2-subunit in childhood absence epilepsy and febrile seizures. Nat Genet 28: $49-52$

Wei W, Zhang N, Peng Z, Houser CR, and Mody I (2003) Perisynaptic localization of delta subunit-containing GABA(A) receptors and their activation by GABA spillover in the mouse dentate gyrus. J Neurosci 23:10650-10661.

Wiltgen BJ, Sanders MJ, Ferguson C, Homanics GE, and Fanselow MS (2005) Trace fear conditioning is enhanced in mice lacking the delta subunit of the GABAA receptor. Learn Mem 12:327-333.

Wisden W, Laurie DJ, Monyer H, and Seeburg PH (1992) The distribution of 13 GABAA receptor subunit mRNAs in the rat brain. I. Telencephalon, diencephalon, mesencephalon. J Neurosci 12:1040-1062.

Witsch J, Golkowski D, Hahn TT, Petrou S, and Spors H (2015) Cortical alterations in a model for absence epilepsy and febrile seizures: in vivo findings in mice carrying a human GABA(A)R gamma2 subunit mutation. Neurobiol Dis 77:62-70.

Wohlfarth KM, Bianchi MT, and Macdonald RL (2002) Enhanced neurosteroid potentiation of ternary GABA(A) receptors containing the delta subunit. $J$ Neurosci 22:1541-1549.

Wu X, Gangisetty O, Carver CM, and Reddy DS (2013) Estrous cycle regulation of extrasynaptic $\delta$-containing $\mathrm{GABA}(\mathrm{A})$ receptor-mediated tonic inhibition and limbic epileptogenesis. J Pharmacol Exp Ther 346:146-160.

Xie XM and Smart TG (1991) A physiological role for endogenous zinc in rat hippocampal synaptic neurotransmission. Nature 349:521-524.

Younus I and Reddy DS (2017) A resurging boom in new drugs for epilepsy and brain disorders. Expert Rev Clin Pharmacol 23:1-19.

Zheleznova NN, Sedelnikova A, and Weiss DS (2009) Function and modulation of delta-containing GABA(A) receptors. Psychoneuroendocrinology 34 (Suppl 1): S67-S73.

Address correspondence to: Dr. Doodipala Samba Reddy, Department of Neuroscience and Experimental Therapeutics, College of Medicine, Texas A\&M University Health Science Center, 2008 Medical Research and Education Building, 8447 Riverside Parkway, Bryan, TX 77807-3260. E-mail: reddy@ medicine.tamhsc.edu 